Additional Perspectives articles for Influenza: The Cutting Edge book collection are available at http://perspectivesinmedicine.cshlp.org/cgi/collection/influenza_the_cutting_edge.

\title{
Pathobiological Origins and Evolutionary History of Highly Pathogenic Avian Influenza Viruses
}

\author{
Dong-Hun Lee, ${ }^{1}$ Miria Ferreira Criado, ${ }^{2}$ and David E. Swayne ${ }^{2}$ \\ ${ }^{1}$ Department of Pathobiology \& Veterinary Science, University of Connecticut, Storrs, Connecticut 06269, USA \\ ${ }^{2}$ Exotic and Emerging Avian Viral Diseases Research Unit, Southeast Poultry Research Laboratory, U.S. National \\ Poultry Research Center, Agricultural Research Service, U.S. Department of Agriculture, Athens, Georgia \\ 30605, USA \\ Correspondence: David.Swayne@ars.usda.gov
}

\begin{abstract}
High-pathogenicity avian influenza (HPAl) viruses have arisen from low-pathogenicity avian influenza (LPAI) viruses via changes in the hemagglutinin proteolytic cleavage site, which include mutation of multiple nonbasic to basic amino acids, duplication of basic amino acids, or recombination with insertion of cellular or viral amino acids. Between 1959 and 2019, a total of 42 natural, independent $\mathrm{H} 5(n=15)$ and $\mathrm{H} 7(n=27) \mathrm{LPAl}$ to HPAI virus conversion events have occurred in Europe $(n=16)$, North America $(n=9)$, Oceania $(n=7)$, Asia $(n=5)$, Africa $(n=4)$, and South America $(n=1)$. Thirty-eight of these HPAl outbreaks were limited in the number of poultry premises affected and were eradicated. However, poultry outbreaks caused by A/goose/Guangdong/1/1996 (H5Nx), Mexican H7N3, and Chinese H7N9 HPAI lineages have continued. Active surveillance and molecular detection and characterization efforts will provide the best opportunity for early detection and eradication from domestic birds.
\end{abstract}

\begin{abstract}
$A$ vian influenza (AI) viruses have their ancesAtry within the ecological niches occupied by aquatic birds, predominately of the orders Anseriformes and Charadriiformes, and these aquatic birds are the primordial reservoir of genes for all Influenzavirus A strains with the exception of the genetic material of H17N11 and H18N12 influenza A viruses, which have been detected only in bats (Webster et al. 1992; Mehle 2014). Currently, AI viruses have surface proteins of any of the 16 different hemagglutinin (H1-16) and nine different neuraminidase (N1-9) subtypes (Swayne et al. 2020). Based on their pathogenicity in chickens, most
\end{abstract}

H1-H16 AI viruses cause mild respiratory, enteric, or reproductive diseases (i.e., low-pathogenicity avian influenza [LPAI]), whereas some of the H5 and H7 AI viruses cause deadly, systemic disease (high-pathogenicity avian influenza [HPAI]).

Historically, the first identification of an AI virus in birds was an HPAI virus, termed fowl plague virus, which was initially identified in Northern Italy during the 1880s (Kaleta and Rulke 2008). Most fowl plague cases were in gallinaceous poultry, principally chicken and turkeys, but some cases also affected geese (Kaleta and Rulke 2008). The affected poultry

Editors: Gabriele Neumann and Yoshihiro Kawaoka

Additional Perspectives on Influenza: The Cutting Edge available at www.perspectivesinmedicine.org

Copyright (C) 2021 Cold Spring Harbor Laboratory Press; all rights reserved; doi: 10.1101/cshperspect.a038679

Cite this article as Cold Spring Harb Perspect Med 2021;11:a038679 
D.-H. Lee et al.

were housed close to migratory waterfowl on river banks such as the River Po. The initial clinical presentation in poultry had a mild course with an abrupt change to highly lethal, rapidly spreading disease very similar to our contemporary understanding of the origins of a HPAI virus through changes in the hemagglutinin (HA) proteolytic cleavage site of a H5 or H7 LPAI virus (Bosch et al. 1979; Kawaoka and Webster 1985; Perdue et al. 1996; Kaleta and Rulke 2008). The fowl plague cases from the 1880 s to 1959 were exclusively H7N7 and H7N1 HPAI viruses, but in 1959, the first H5 HPAI virus appeared in chickens in Scotland, H5N1 (Kaleta and Rulke 2008; Swayne et al. 2020). From the 1880 s to 1959 , fowl plague spread throughout Europe, Asia, and Africa and was reported from North and South America. However, it is unclear if these fowl plague cases were a single HPAI virus lineage that was maintained and widely spread geographically among poultry populations or if there were multiple local occurrences of LPAI viruses giving rise to HPAI viruses, but with a more restricted geographic spread. The lack of knowledge related to uniqueness of virus isolates prior to 1959 severely limited the maintenance of diverse and unique fowl plague isolates, which are available today for genetic analysis (Swayne 2008a). However, since 1959, with well-maintained unique virus isolates in archives, outbreaks caused by HPAI viruses have mostly arisen from virulence shifts by LPAI viruses with limited spread and eradication from poultry via stamping out programs. The major exception has been the A/goose/Guangdong/1/ 1996 (Gs/GD) lineage of H5, which arose in 1996 and has spread and been maintained in poultry and wild aquatic bird reservoirs until the current date, producing infections in poultry, wild birds, or humans in 84 countries in Asia, Africa, Europe, and North America (Röhm et al. 1995; Swayne et al. 2020). The first LPAI virus from poultry was identified in chickens in Germany in 1949 (Dinter virus, H10N7) (Swayne 2008a), and the first LPAI viruses in wild waterfowl (Slemons et al. 1974) and pelagic seabirds (Downie and Laver 1973) were identified in 1972, although antibodies to Influenza- virus $A$ had been detected in migratory waterfowl as early as 1968 (Easterday et al. 1968).

This review will discuss the mechanisms and genetic changes in the HA gene that are responsible for the shift from LPAI to HPAI viruses and analyze the genetic information, demonstrating that HPAI viruses belong to distinct lineages (Table 1).

\section{MECHANISMS OF THE EMERGENCE OF H5 AND H7 HPAI VIRUSES}

The phenotype classification of avian influenza into LPAI (H1-16) and HPAI (H5 and H7) viruses is based on in vivo testing (i.e., the ability to produce severe lethal disease in chickens on intravenous inoculation) and molecular characteristics of the HA protein, more specifically as changes in the proteolytic cleavage site (OIE 2019b). According to the 12th Organisation for Animal Health (OIE) Terrestrial Animal Health Code, the H5 and H7 AI viruses classified as HPAI virus should have an intravenous pathogenicity index (IVPI) in 6-wk-old chickens of $>1.2$ (OIE 2002). Beginning with the 13th edition of the Terrestrial Animal Health Code (OIE 2004), H5 and H7 AI viruses with IVPI of $\leq 1.2$ or lethality of $<75 \%$ should be sequenced to determine whether multiple basic amino acids are present at the cleavage site of the HA. If similar sequences of the cleavage site have been observed for other previously reported HPAI viruses, the virus should be classified as HPAI virus. These regulatory definitions are still in place in 2019 (OIE 2019b). However, the presence of any insertion that lengthens the cleavage site but has not been previously reported should be discussed with an OIE Avian Influenza Reference Laboratory or Collaborating Centre before classifying the virus as LPAI or HPAI virus (OFFLU 2019). Although most of the HPAI chicken viruses emerged from LPAI precursors in aquatic wild birds, the emergence of HPAI viruses does not always occur in gallinaceous host (Swayne et al. 2020). The detailed steps of how LPAI viruses evolve into HPAI viruses are not completely understood, but molecular techniques such as next-generation sequencing and reverse genetics have helped to identify the HA 


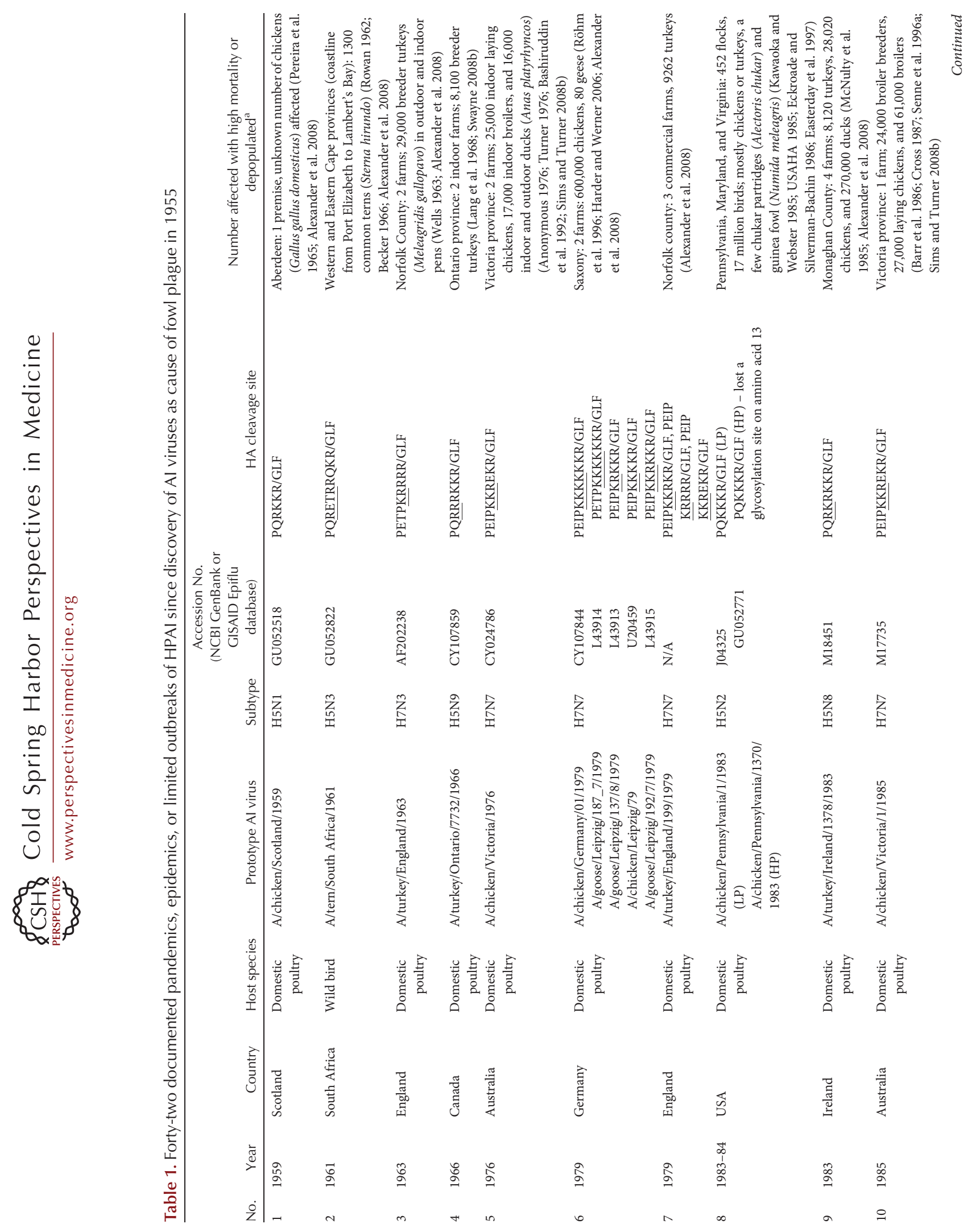




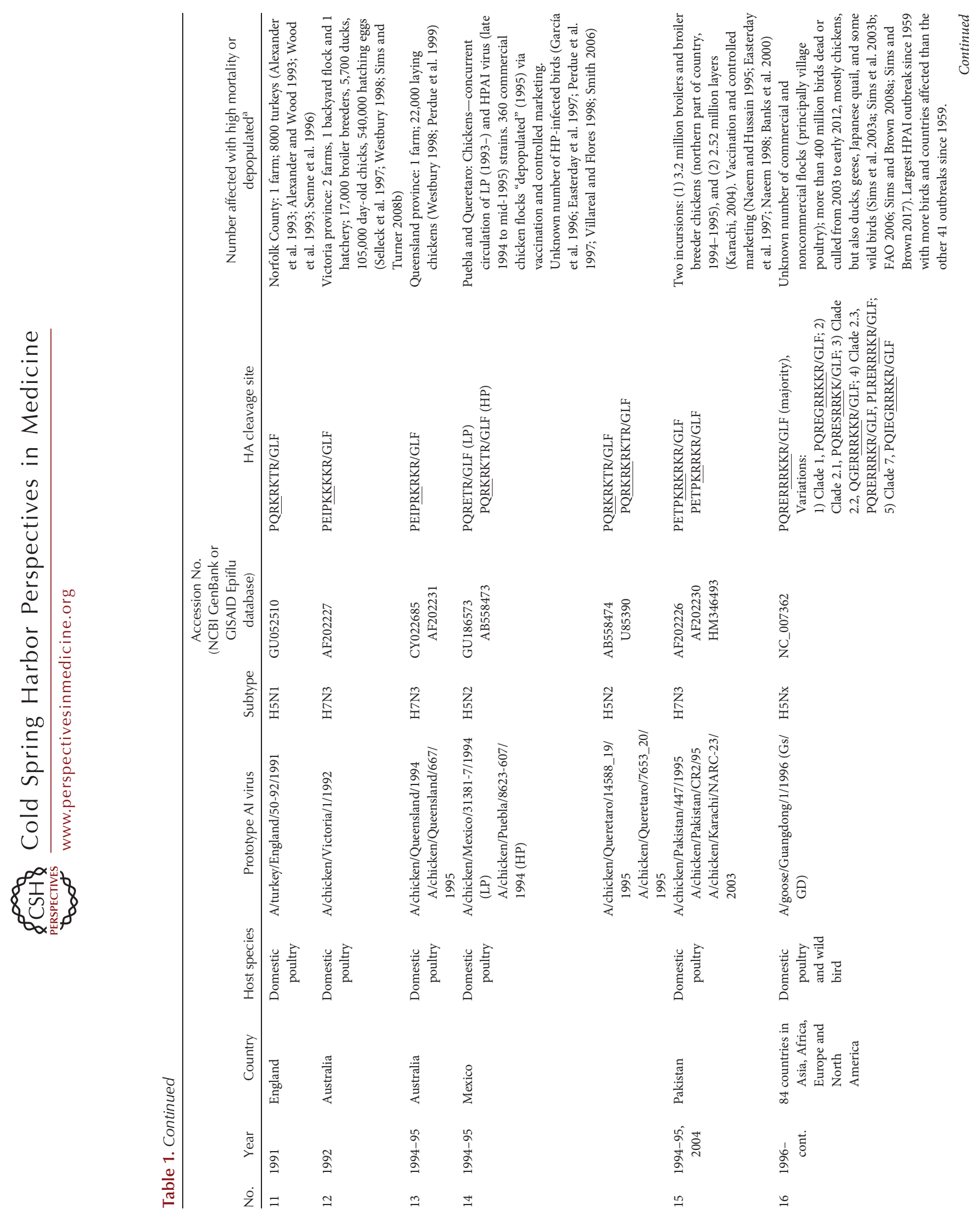



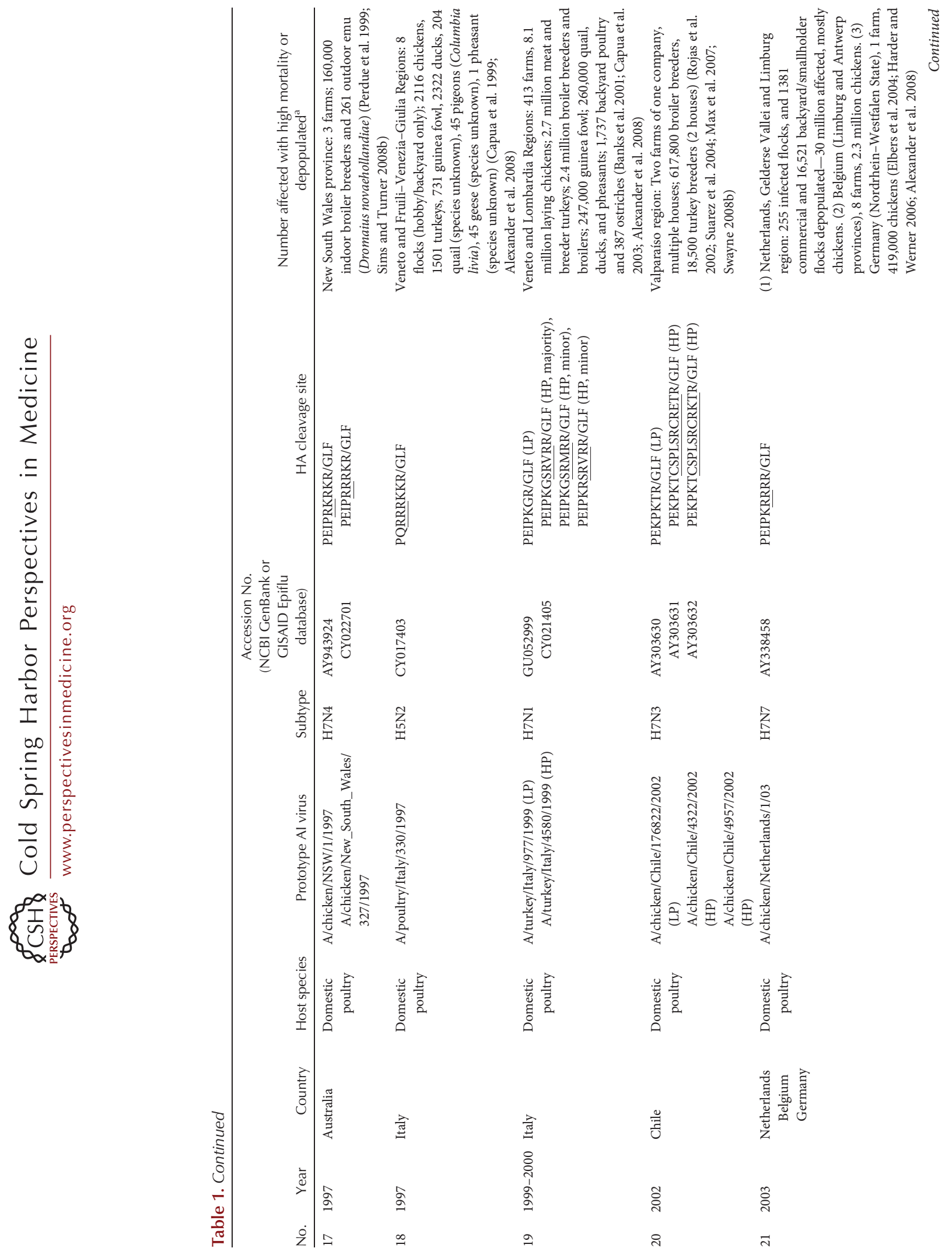

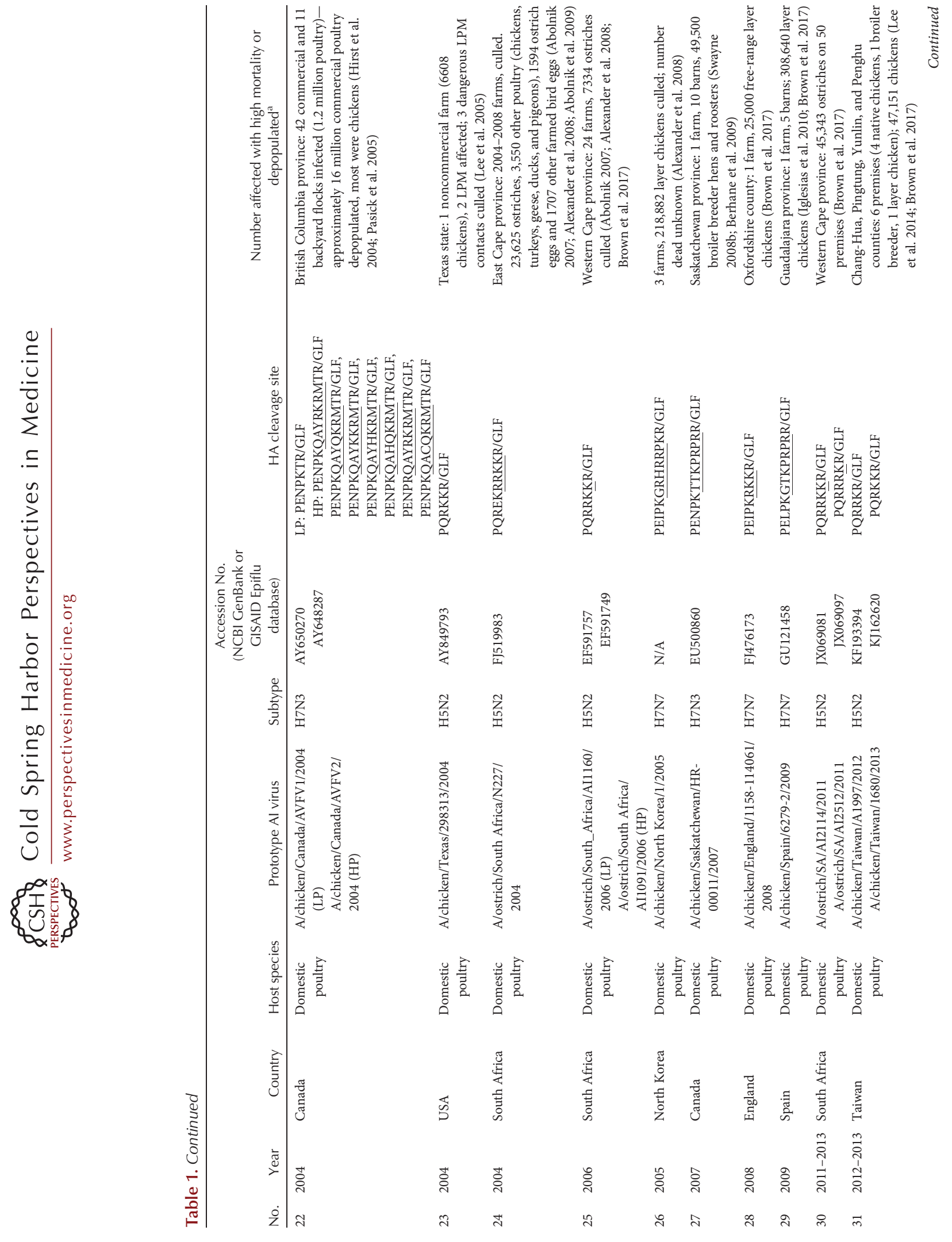

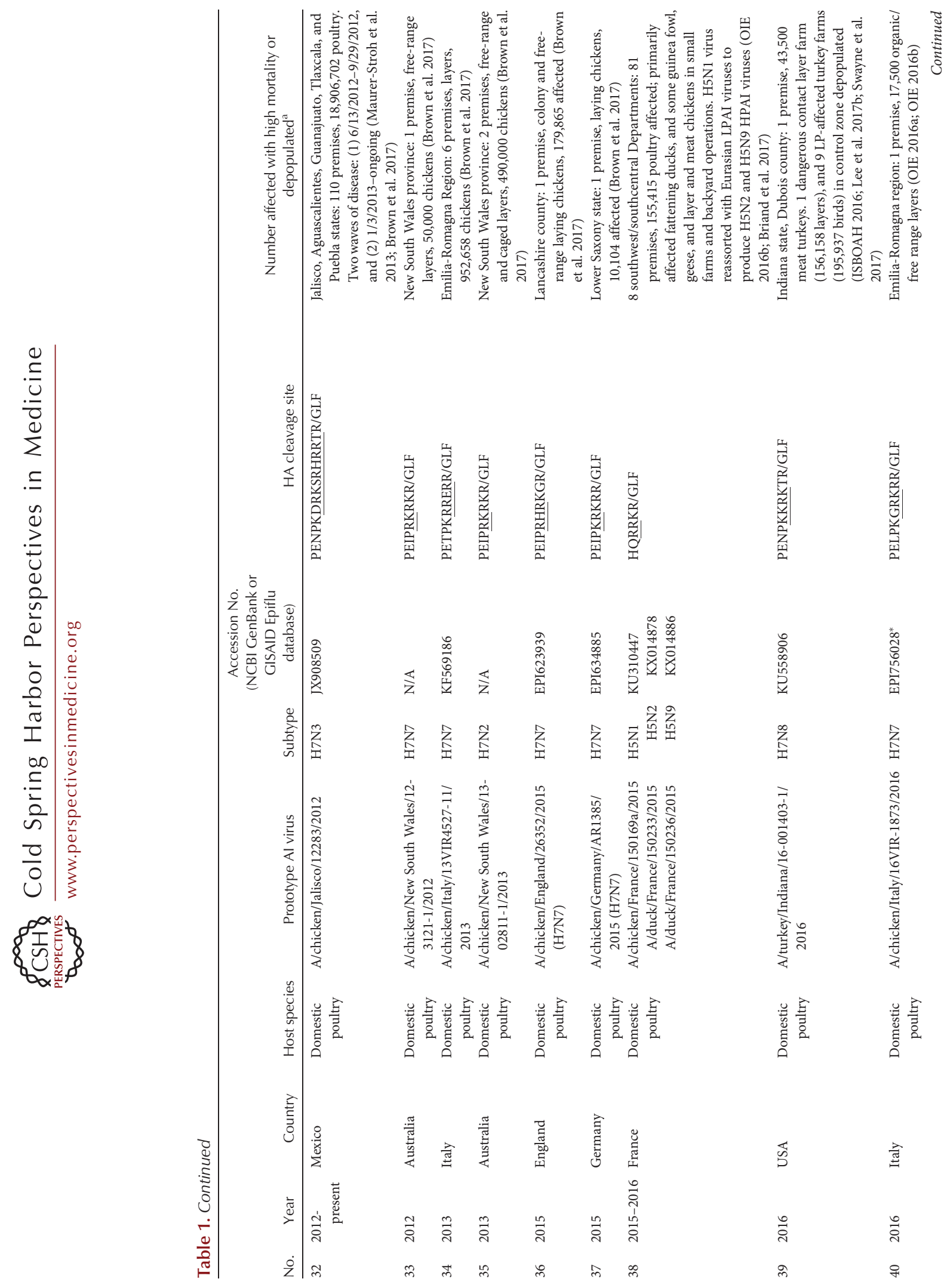

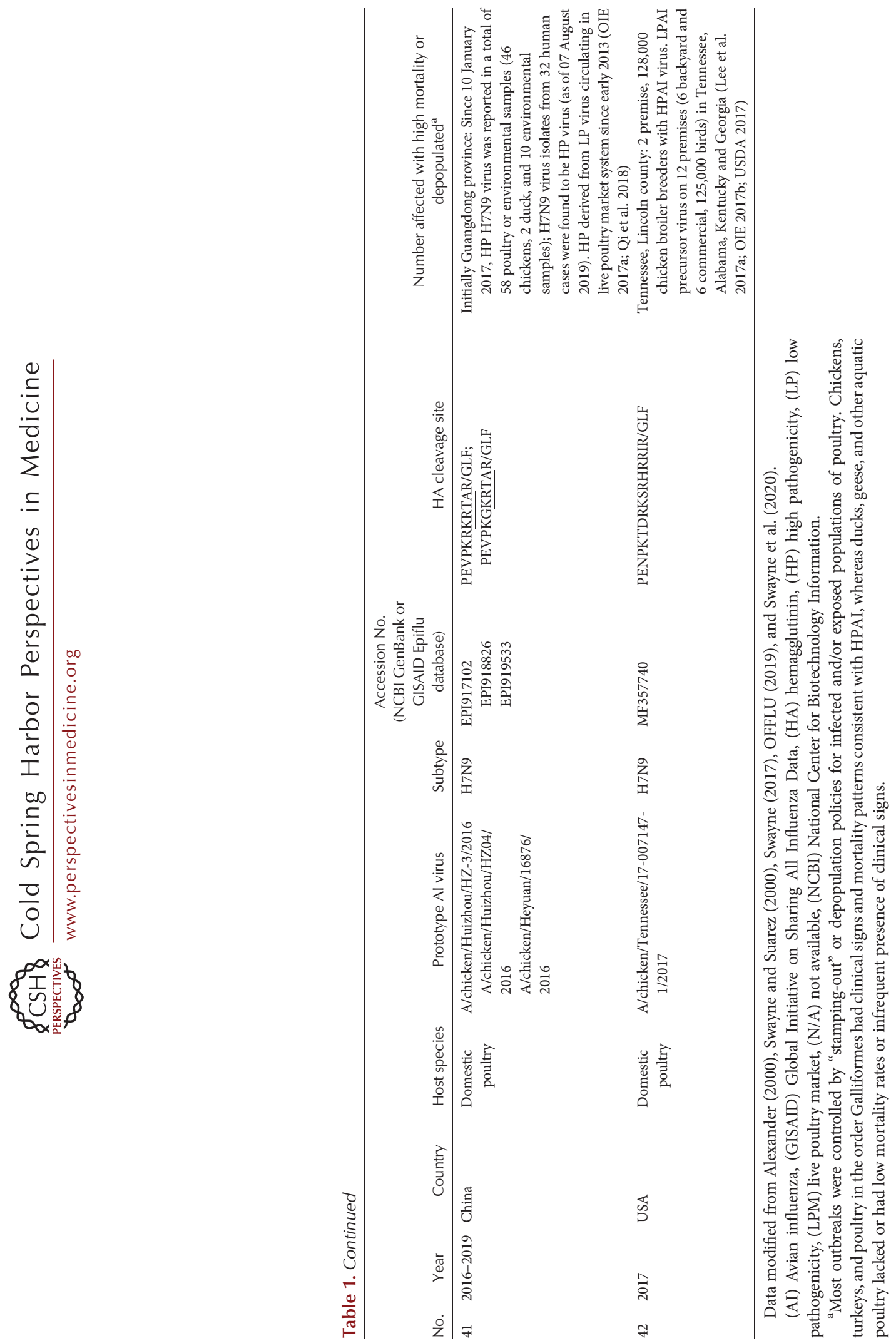
cleavage site changes associated with high virulence. In addition, changes in other AIV gene segments can affect the phenotype, usually through increased replication efficiency and virus particle release.

The mechanisms by which $\mathrm{H} 5 / \mathrm{H} 7$ LPAI viruses change into HPAI virus include mutation, insertion, and recombination in the proteolytic cleavage site of the HA. The HA is the AI virus surface glycoprotein responsible to attach the virus to the host cell receptor to initiate the infection life cycle. After the virus enters the cell the new viruses start to be produced, including the inactive precursor HA protein (HA0). The $\mathrm{HA} 0$ is cleaved at the proteolytic cleavage site by cellular proteases of the host to form the functional subunits HA1 and HA2, resulting in an infectious virus. The cleavage site region in the HA 0 consists of an arginine (R) residue adjacent to a conserved glycine (G) (Garten and Klenk 1983; Swayne et al. 2020). The number of basic amino acids at the HA cleavage site plays a critical role in virulence by determining which proteases cleave the HA0 and consequently in which cell types and tissues in the host the AI viruses can replicate (Bosch et al. 1981; Kawaoka et al. 1987; Horimoto and Kawaoka 1994; Swayne et al. 2020). First, the AI virus HA cleavage site can be classified as a monobasic (e.g., PEKQTR/GLF) or multibasic (e.g., PQRKKR/ GLF). The monobasic cleavage site usually contains one or two nonconsecutive basic amino acids, arginine $(\mathrm{R})$ or lysine $(\mathrm{K})$, in the critical position and is cleaved by trypsin or trypsin-like proteases that confines virus replication in the epithelial cells of the respiratory and gastrointestinal tracts (Suarez 2016; Swayne et al. 2020). The H5/H7 LPAI viruses maintain the general principle of monobasic cleavage site, although in the wild birds, these subtypes have varying patterns of amino acids at the cleavage site (Suarez 2016). The H5 LPAI viruses usually encode the QRETR/G sequence, whereas H7 LPAI viruses typically possess the NPKTR/G sequence at the cleavage site. An increased number of basic amino acids and/or a lengthening of the proteolytic cleavage site to a minimum motif of four basic amino acids change the virus to high virulence by allowing the HA0 to be cleaved by several ubiquitous cellular proteases (furinlike proteases), which permit the virus to replicate in cells of multiple tissues, increasing the potential to cause a systemic disease and lethal infection in gallinaceous host (OIE 2019b; Swayne et al. 2020). More specifically, the changes observed in the HA cleavage site of HPAI viruses occurred because of (a) substitutions of nonbasic with basic amino acids and in some situations accompanied by loss of a shielding glycosylation site, (b) insertions of multiple basic amino acids from codons duplicated, (c) short inserts of basic and nonbasic amino acids from unknown source, or (d) nonhomologous recombination with cellular (e.g., host $28 \mathrm{~S}$ RNA) or viral RNAs (e.g., RNA coding NP or M protein) that lengthen the proteolytic cleavage site. The changes (a), (b), and (c) have been observed in the H5/H7 HPAI viruses, whereas (d) has only been observed in H7 HPAI viruses (Suarez et al. 2004; Pasick et al. 2005; MaurerStroh et al. 2013; Swayne et al. 2020).

As illustrated in Table 1, the length of the multibasic cleavage site varies between different HPAI viruses within or between different outbreaks. Analysis of naturally occurring H5 HPAI viruses shows a preference of the cleavage site to harbor two additional basic amino acids residues for a total of four basic amino acids (Table 1), but additional basic amino acids do not increase the pathogenicity in chickens (Alexander et al. 1986; Suarez 2016). Experiments by reverse genetics confirmed that five or more basic amino acids in the cleavage site are preferentially selected with high viral fitness in chicken over those with fewer insertions (Luczo et al. 2018). Some studies suggest that the potential role of the polymerase slippage facilitates the incorporation of additional basic residues into the HA cleavage site (Perdue et al. 1997; Abolnik 2017; Nao et al. 2017). Other studies indicate that increased spacing in the cleavage site loop appears to play an important role in the virulence instead of just adding basic amino acids (Suarez 2016). Furthermore, in silico analysis suggests that potential RNA secondary structures in the cleavage site regions of $\mathrm{HA}$ segments, having conserved stem-loop structures with cleavage site codons in the hairpin 
D.-H. Lee et al.

loops, may facilitate evolution toward an multibasic cleavage site, although future experimental studies should be done to clarify the structurefunction relationships in these domains for $\mathrm{H} 5$ and $\mathrm{H} 7$ subtypes compared to other subtypes that have not had LPAI to HPAI phenotype changes (Gultyaev et al. 2019). Interestingly, reverse genetic approaches show that the virus loses the ability to cause severe disease when the multibasic antigenic site motif or specific basic residues of HPAI viruses are removed (Kawaoka and Webster 1988; Walker and Kawaoka 1993; Horimoto and Kawaoka 1994, 1997; Walker et al. 1994; Lu et al. 2006; Bogs et al. 2010; Gohrbandt et al. 2011). In general, the mechanisms for amino acid insertions in the cleavage site appear to be different in many cases, and for this reason the genetic basis to predict which LPAI viruses will result in the emergence of a HPAI virus remains unclear.

Other important mechanisms that alter the AI virus phenotype include the presence or absence of N-linked glycans and changes in histidine 184 residue or the adjacent $\mathrm{E} 216(\mathrm{R} / \mathrm{K})$ in HA. The glycosylation sites, especially in the HA stalk, can influence the protease accessibility to the cleavage site. Apart from the important glycosylation site at the position 10-12 (AsnAsn-Ser) in the HA of the H5N2 HPAIV outbreak in Pennsylvania in 1983 (Kawaoka et al. 1984), other potential glycosylation sites have been demonstrated to affect the AI viruses' pathogenicity (Kawaoka and Webster 1989; Hulse et al. 2004; Zhang et al. 2015). The glycosylation sites in the HA are also shown to contribute to the virus replication and chicken-to-chicken transmission, which consequently affect the AI virus virulence (Abdelwhab et al. 2016; Swayne et al. 2020). The presence of critical key histidine residues in the HA can affect the conformational changes postcleavage. Reports show that mutations at or close to histidine 184 at the HA1HA1 interface modulate the $\mathrm{pH}$ dependence and consequently the HA conformation (Mair et al. 2014). Alignments of the HA sequences from H5N1 HPAI viruses show that a Glu-toArg mutation at position 216 close to His 184 can possibly contribute to AI virus adaptation to hosts (Mair et al. 2014). Other studies demonstrated that mutations altering the $\mathrm{pH}$ of fusion modulate $\mathrm{H} 5 \mathrm{~N} 1$ virus pathogenicity in avian and mammalian host (Reed et al. 2010; DuBois et al. 2011; Zaraket et al. 2013a,b; Russell 2014).

Although the HA is the major determinant of virulence in AI viruses, the modulation of pathogenesis from LPAI to HPAI virus in domestic chickens may involve multiples genes. Comparison of the genetic changes between LPAI virus precursors and HPAI viruses in outbreaks between 1966 and 2016 show that, even though mutations were observed in other genes, changes mainly occur in the HA and polymerase (e.g., PA) gene (Richard et al. 2017). The number of changes varies from 7 to 68 substitutions without any association as a prerequisite of HPAI virus emergence (Richard et al. 2017). It is still unknown if the changes naturally observed in the evolution from LPAI to HPAI viruses in the field are only a selection of viruses adapted to replicate in several tissues. Most of the time, specific selection procedures (i.e., virus isolation without exogenous trypsin, etc.) are necessary to recover HPAI virus, which likely represent minority variants present in the field. Moreover, experimental studies show that mutation in the carboxy terminal at the nonstructural 1 (NS1) protein and neuraminidase (NA) stalk deletion during the change from LPAI to HPAI virus may contribute to virulence, increasing virus shedding and poultry adaptation (Senne et al. 1996; Keiner et al. 2010; Munier et al. 2010).

Therefore, besides all the available data, further studies are still necessary to better understand the modulation of virulence from LPAI to HPAI virus.

\section{UNIQUE GENETIC LINEAGES ASSOCIATED WITH AVIAN HPAI OUTBREAKS}

Table 1 lists the summaries and references of HPAI outbreaks between 1959 and 2017 based on epidemiological data, peer-reviewed publication, and published OIE reports. As of August 2019, a total of 42 independent H5 and H7 LPAI to HPAI conversion events have been documented since the discovery of AI viruses as the 
Origins and Evolution of HPAI Viruses

cause of fowl plague in 1955 (i.e., HPAI [Swayne 2017; Dhingra et al. 2018; Swayne et al. 2020]). More specifically, for these 42 conversion events, 27 were $\mathrm{H} 7$ subtype (11 in Europe, seven in Oceania, five in North America, three in Asia, and one in South America) and 15 were H5 subtype (five in Europe, four in Africa, four in North America, and two in Asia) (Fig. 1). The highest number of conversions were documented in Europe $(n=16)$, followed by North

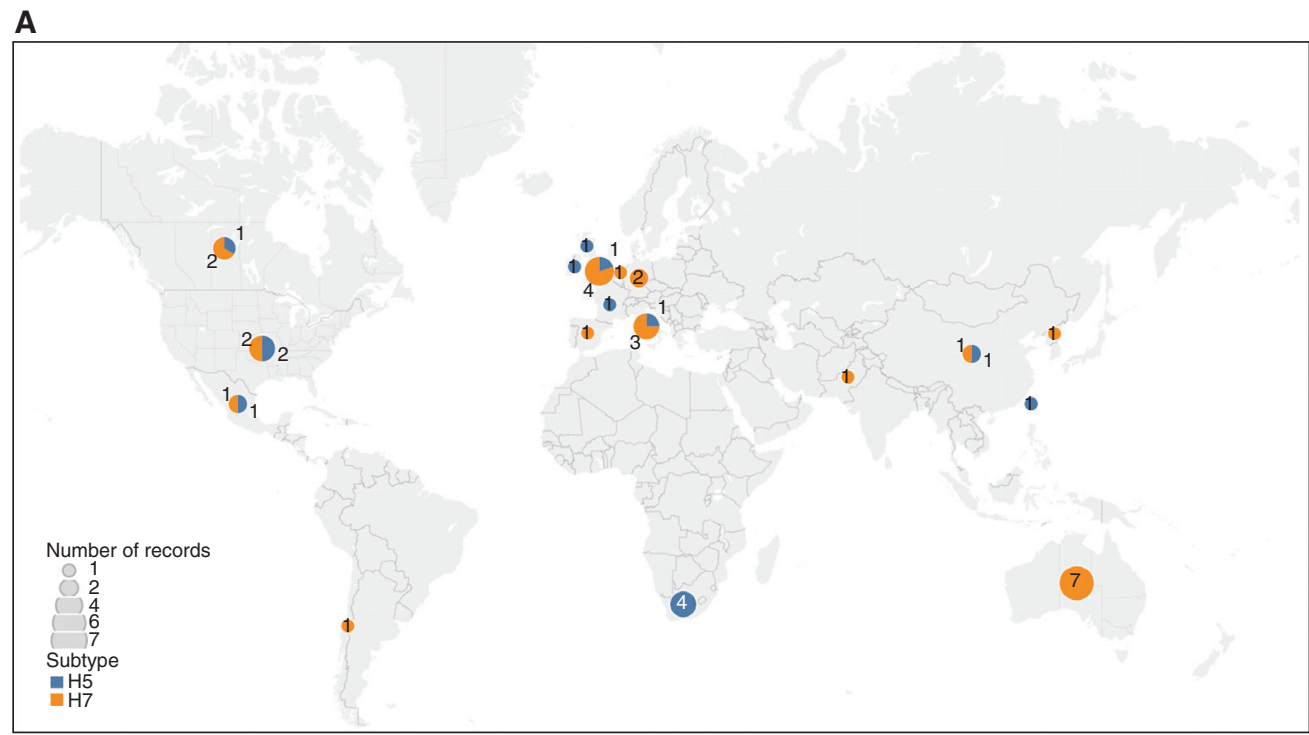

B

Continent Country

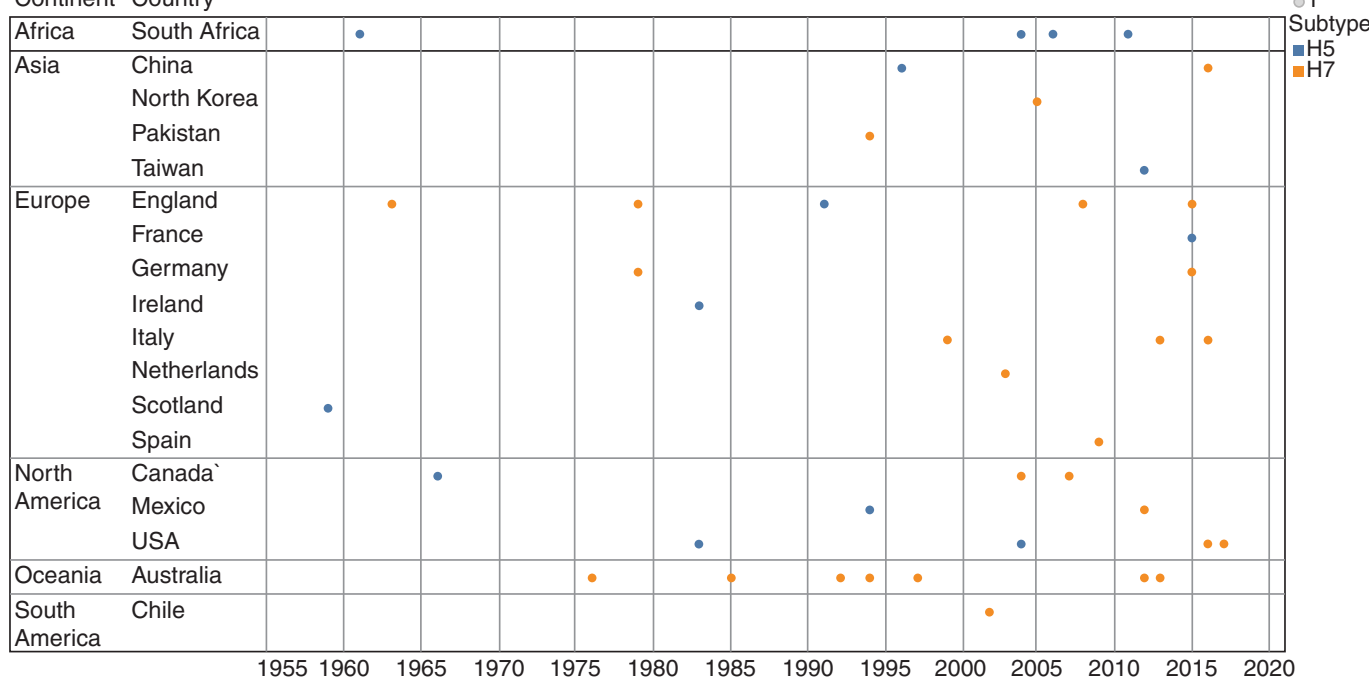

Figure 1. Geographic origin of $\mathrm{H} 5$ and $\mathrm{H} 7$ high-pathogenicity avian influenza viruses by country from 1959 to 2019. (A) Map based on average of longitude and average of latitude. Color shows details about subtype. Size shows sum of number of records. The marks are labeled by sum of number of records. Details are shown for each country. (B) Year for each country broken down by continent. Color shows details about subtype. Size shows number of records. 
D.-H. Lee et al.

America $(n=9)$, Oceania $(n=7)$, Asia $(n=5)$, Africa $(n=4)$, and South America $(n=1)$. Among these 42 conversions, 40 outbreaks involved domestic poultry (principally chickens and turkeys), the South Africa outbreak (1961) involved exclusively wild birds, and the outbreak of Gs/GD lineage of H5 (1996-present) involved both domestic poultry and wild birds.

Genome sequencing data has been used to determine the pathogenicity based on the genetic sequences of the HA cleavage site and to trace the origin of viruses using a molecular epidemiological approach. Particularly, phylogenetic analysis and the use of direct sequence comparisons between isolates have provided important clues about the ancestry of outbreak strains. We were able to obtain all HA gene sequences of LPAI to HPAI conversions events, except three H7 outbreaks: 1979 H7N7 outbreak in England, and 2012 and 2013 H7N7 outbreaks in Australia. All available recorded conversions of the H5 and H7 HPAI viruses since 1959 were phylogenetically analyzed. All H7 and non-Gs/GD H5 nucleotide sequences from avian species were downloaded from the Influenza Research Database (www.fludb.org). We then removed identical nucleotide sequences with $\geq 98 \%$ (H7) and $98.5 \%$ (non Gs/Gs H5) identity using the Cluster Database at High Identity with Tolerance (CD-HIT) (Li and Godzik 2006), resulting in representative strains that form the final set of nonredundant sequences. Representative Gs/GD H5 nucleotide sequences were added in the H5 data set. Sequences (H5: $n=298$, H7: $n=250$ ) were aligned using multiple alignment with fast Fourier transformation (MAFFT) in the Geneious v8.1.2 program and trimmed to remove nucleotides that were outside the coding region. The Bayesian relaxed clock phylogenetic analysis of the HA gene was conducted using BEAST v1.10.4. with an uncorrelated lognormal distribution relaxed clock method, the HKY nucleotide substitution model and the Gaussian Markov random field (GMRF) Bayesian skyride coalescent prior (Minin et al. 2008). All 39 documented HPAI outbreaks were phylogenetically different from each other (Fig. 2A,B). Each branch of documented HPAI virus reflects the independent conversion from a LPAI ancestor to HPAI virus.

In Europe, the emergence of HPAI viruses was recorded on 16 occasions in England ( $n=5$; H5 in 1991, H7 in 1963, 1979, 2008, 2015), Italy $(n=4$; H5 in 1997, H7 in $1999,2013,2016)$, Germany ( $n=2$; H7 in 1979, 2015), Scotland $(n=1$; H5 in 1959), Ireland $(n=1 ; \mathrm{H} 5$ in 1983), Netherland ( $n=1 ;$ H7 in 2003), Spain $(n=1 ;$ H7 in 2009), and France $(n=1 ;$ H5 in 2015) between 1959 and 2015. It has been suggested that the two outbreaks in 1979, in Germany and England, may have represented a single emergence of H7N7 HPAI virus that was spread by wild birds (Alexander and Brown 2009). It was not possible to genetically compare the two outbreaks in Germany and England during 1979 because the genetic sequence of 1979 H7N7 viruses in England was not available in public databases. The phylogenetic tree in a previous study suggested that they have emerged from a same close LPAI common ancestor (Banks and Plowright 2003). However, the HA cleavage sites of the Germany and England viruses have a slightly different multibasic cleavage site as shown in Table 1. These findings suggest that these viruses were converted from LPAI to HPAI viruses independently from the same close common ancestor circulating in Western Europe during 1979.

In North America, the emergence of HPAI viruses was recorded on nine occasions during 1966-2017, including the United States $(n=4$; H5 in 1983, 2004; H7 in 2016, 2017), Canada $(n=3$; H5 in 1966; H7 in 2004, 2007), and Mexico ( $n=2$; H5 in 1994, H7 in 2012). On the other hand, there was only one occasion in South America (Chile, H7 in 2002). All of these HPAI outbreaks were eradicated from poultry, except the Mexican HPAI H7N3 outbreak. The Mexican HPAI H7N3 has continued to cause outbreaks in commercial chickens in Mexico since the first case in 2012 (OIE 2019a).

In Oceania, only Australia has had seven emergences of HPAI in poultry during 19762013, all of them the H7 subtype (H7N7 in 1976 and 1985, H7N3 in 1992 and 1994, H7N4 in 1997, H7N7 in 2012, and H7N2 in 2013). In addition, the devastating Gs/GD 


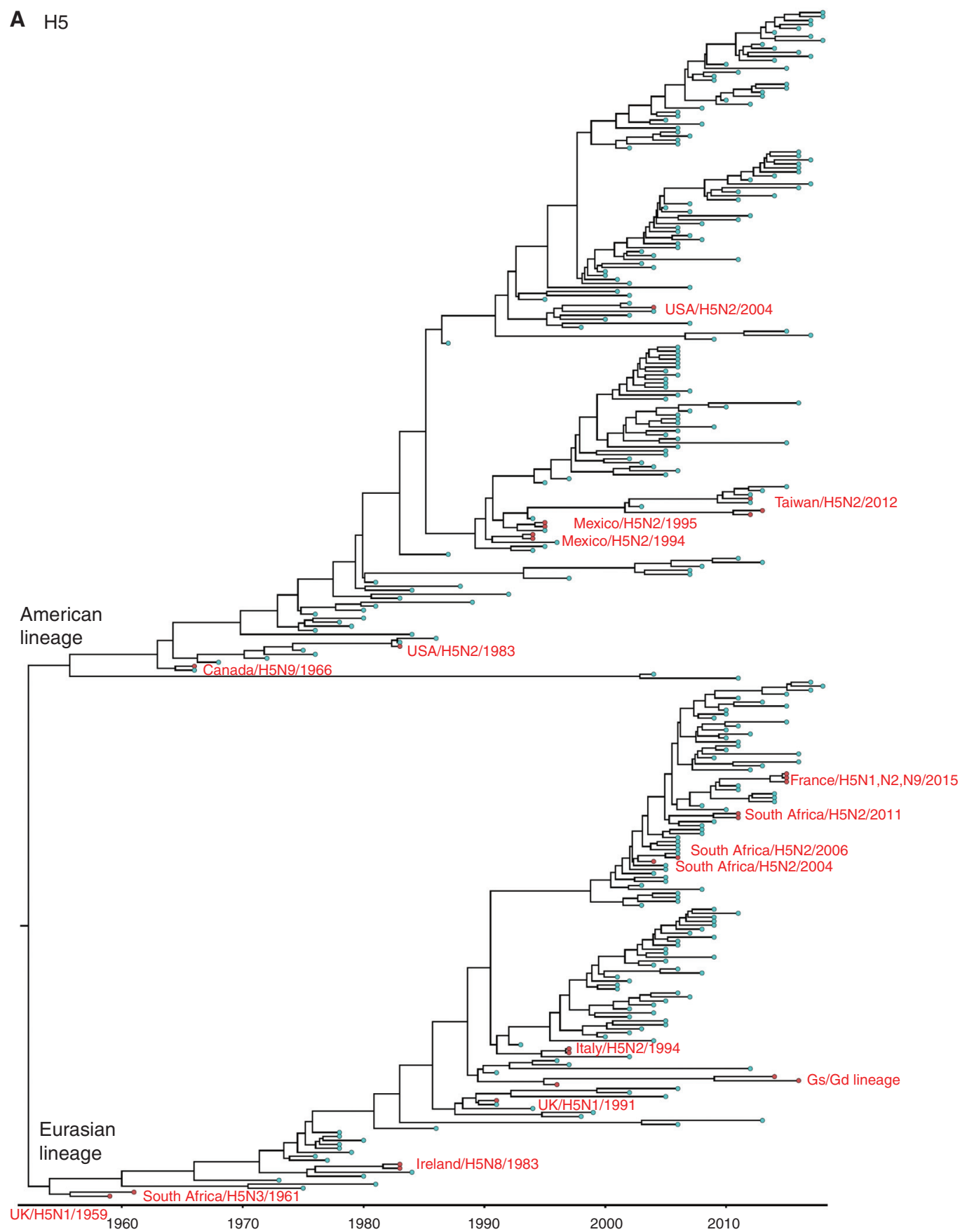

Figure 2. Bayesian relaxed clock phylogenetic analysis of the H5 $(A)$ and $\mathrm{H} 7(B)$ HA genes for 39 high-pathogenicity avian influenza viruses that emerged since 1959. 
D.-H. Lee et al.

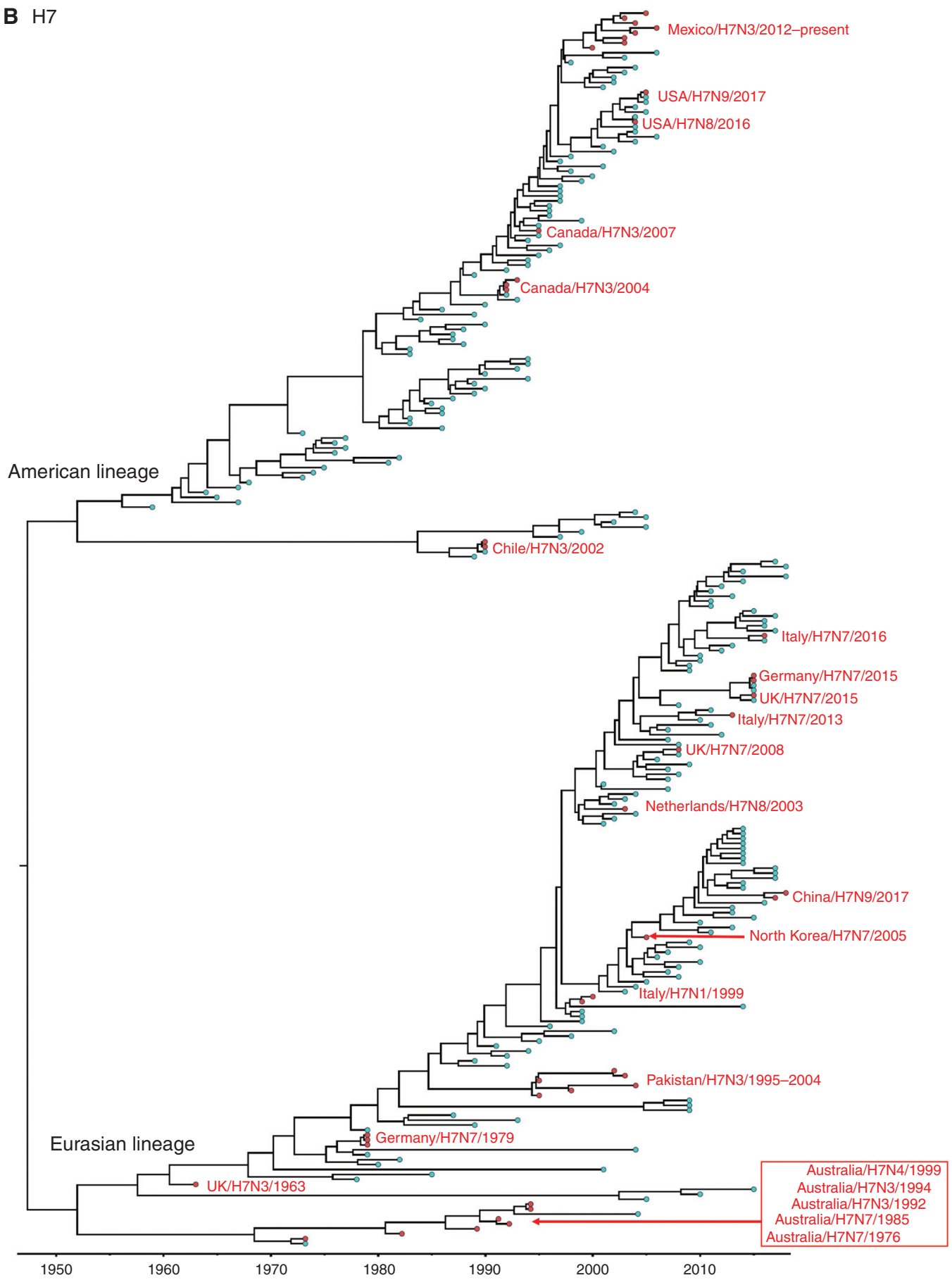

Fig. 2. Continued. 
H5Nx HPAI viruses have not been detected in Oceania. All H7 HPAI strains identified in Australia belong to the Australian lineage (Fig. 2 ). The two recent outbreaks in Australia were not included in the phylogenetic analysis because the HA gene sequences of the 2012 H7N7 and 2013 H7N2 strains were not available in public databases. It has been documented that H7 LPAI viruses similar to that found in the H7N7 outbreak in 2012 and the H7N2 outbreak in 2013 were unrelated samples from Australian wild waterfowl that have been circulating in Australia for many years (Wong and Daniels 2013).

In Asia, a total of five conversions have been recorded, including China $(n=2$; Gs/GD H5N1 in 1996 and H7N9 in 2016), Pakistan $(n=1$; H7N3 in 1994), North Korea $(n=1$; H7N7 in 2005), and Taiwan ( $n=1$; H5N2 in 2012). Phylogenetic analysis shows that all HPAI strains that were identified in Asia emerged from Eurasian LPAI viruses, except the H5N2 HPAI identified in Taiwan during 2012, which clustered with Mexican H5N2 viruses (Fig. 2). The high similarity of the Taiwanese $\mathrm{H} 5 \mathrm{~N} 2$ viruses to the Mexican $\mathrm{H} 5 \mathrm{~N} 2$ vaccine strain suggests that the Mexican H5N2 viruses might have been introduced to Taiwan by using inadequately inactivated or attenuated Mexican H5N2 vaccines (Lee et al. 2014).

Unlike most previous HPAI virus epizootics that have been geographically limited, involving sporadic interfarm transmissions, and were eradicated from poultry by stamping-out programs, the Gs/GD lineage has caused deaths in wild birds, poultry, and mammals including humans and has spread to 84 countries in Asia, Europe, Africa, and North America as of August 2019. The first Gs/GD lineage H5N1 HPAI virus was identified in a domestic goose in southern Guangdong province of China in 1996 and this lineage has evolved into 10 genetically distinct virus clades (0-9) and multiple subclades (WHO/OIE/FAO_H5N1_Evolution_Working Group 2008, 2014). There have been four waves of intercontinental transmission of Gs/GD lineage H5Nx virus (Figs. 3A-C; Sims et al. 2017). Briefly, the first intercontinental wave in 20052006 caused by a clade 2.2 H5N1 HPAI virus involved China, Mongolia, Russia, Central Asia, Europe (widespread: over 20 European countries), Middle East, West Africa, Japan, and Republic of Korea (Fig. 3A). The second intercontinental wave in 2009-2010 caused by a clade 2.3.2.1c H5N1 HPAI virus involved mostly East Asia (China, Mongolia, Japan, and Republic of Korea), but was also found in Eastern Europe (Russia, Romania, and Bulgaria) and Nepal (Fig. 3B). The third intercontinental wave in 20142015 involved two separate viral lineages, clade 2.3.4.4a $\mathrm{H} 5 \mathrm{Nx}$ (wave 3a) (Fig. 3C) and clade 2.3.2.1c H5N1 that differed from the 20092010 isolate (wave 3b) (Fig. 3B). The wave 3a was caused by a clade 2.3.4.4a H5N8 HPAI virus originated from East Asia that had spread rapidly and globally through wild birds and evolved through reassortment with prevailing local LPAI viruses to produce multiple $\mathrm{H} 5 \mathrm{Nx}$ viruses. The wave $3 \mathrm{~b}$ caused by a clade 2.3.2.1c H5N1 involved Russia, China, Middle East, West Africa, Cameroon, Romania, Bulgaria, and Central Asia. The fourth intercontinental wave in 20162017 caused by a clade 2.3.4.4b H5Nx involved Asia (East, Central, and South), Middle East, Europe (widespread), and Africa (West Central, East, and Southern) (Fig. 3C). The Gs/GD lineage has not been eradicated and still poses a serious threat to the poultry industry and public health as well. Additionally, LPAI H7N9 viruses have been a threat to public health since their emergence in 2013 in China (see Chen 2019). It has mutated into HPAI and caused human infections and outbreaks among poultry since 2016 (Yang et al. 2017).

In Africa, only South Africa has had four emergences of HPAI during 1961-2013, which were caused by viruses of the $\mathrm{H} 5$ subtype (H5N3 in 1961 and H5N2 in 2004, 2006, and 2011). The phylogenetic tree suggests that the H5N2 identified in 2004 and 2006 have emerged from the same close LPAI common ancestor. In a previous study, molecular and phylogenetic characterization was performed to determine whether the 2006 outbreak strain was supposedly derived from the eradicated 2004 H5N2 strain (Abolnik 2007). It was demonstrated that although the 2004 and 2006 H5N2 strains shared a common ancestor, the two outbreaks 
D.-H. Lee et al.
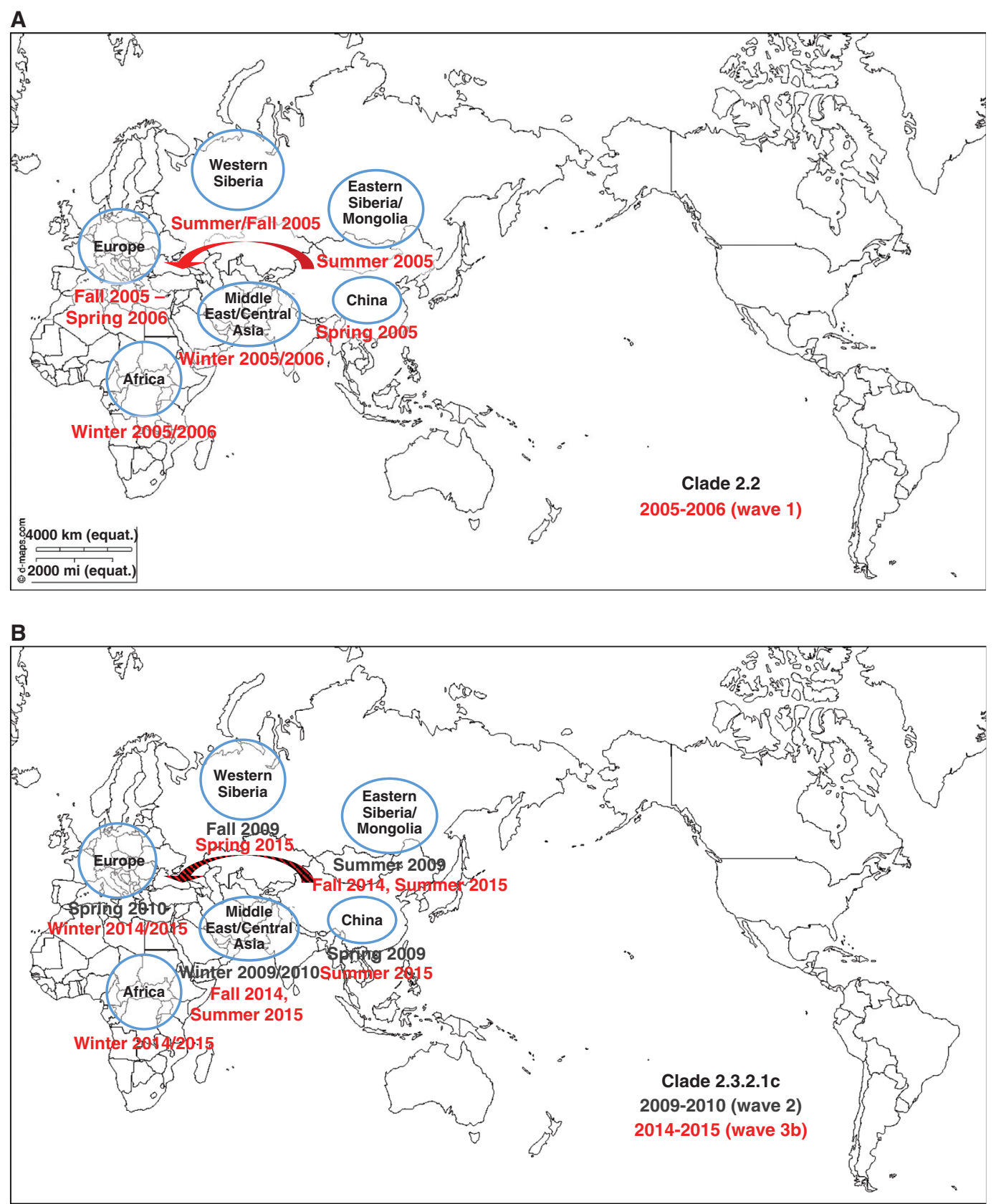

Figure 3. Four waves of intercontinental transmission of Gs/GD lineage H5Nx virus: (A) Clade 2.2, 2005-2006, wave 1. (B) Clade 2.3.2.1c, 2009-2010, wave 2; Clade 2.3.2.1.c, 2014-2015, wave 3b. (C) Clade 2.3.4.4a, 2014-2015, wave 3a; Clade 2.3.4.4b, 2016-2017, wave 4. (Maps modified, with permission, from https://d-maps.com/carte .php?num_car=3503\&lang=en.) 
C

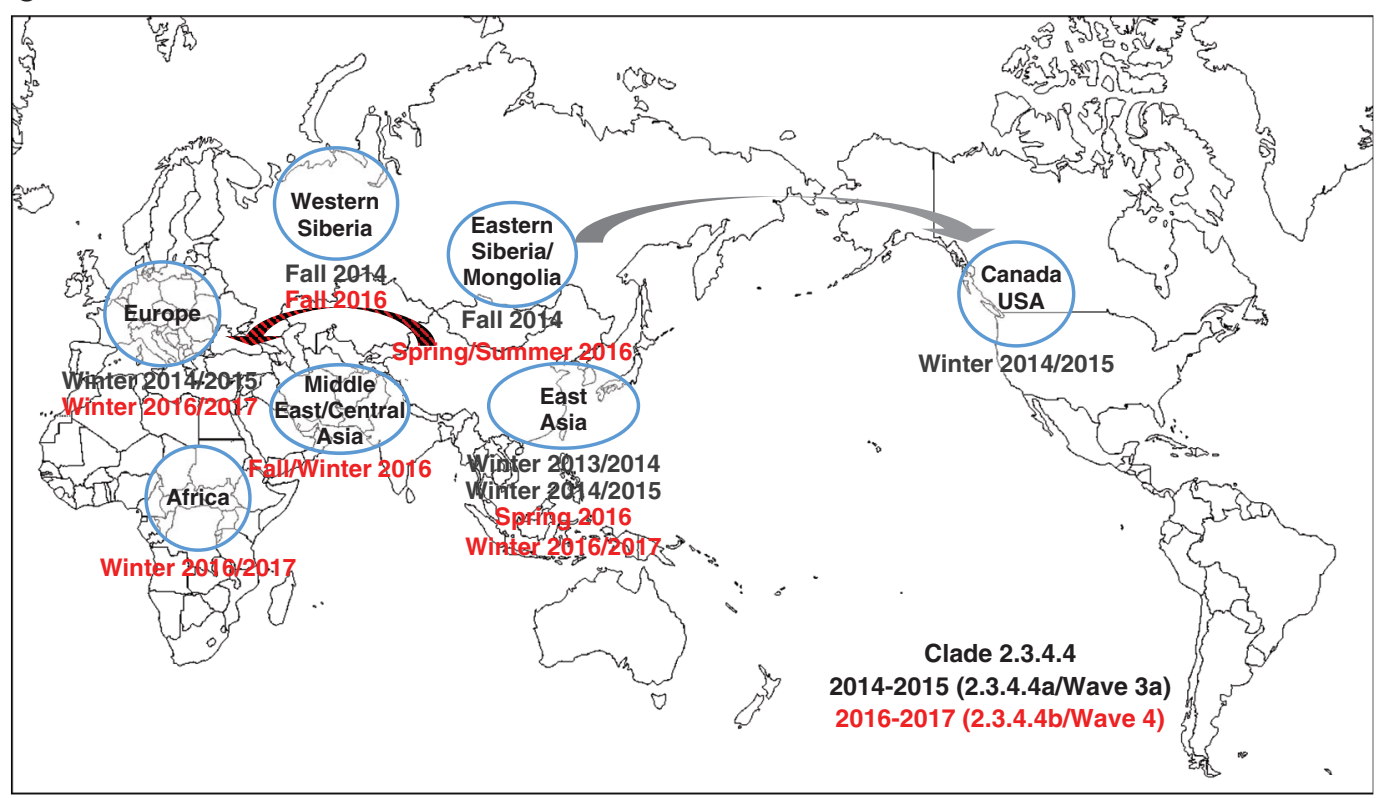

Fig. 3. Continued.

were not related. Not only were extensive reassortments with wild bird viruses involved in the evolution of the 2006 strains, but also the HA cleavage site sequence of the $2006 \mathrm{H} 5 \mathrm{~N} 2$ virus contained fewer monobasic amino acid insertions (Abolnik 2007).

\section{CONCLUDING REMARKS}

Historically, the first AI virus in birds was identified in the 1880s as an HPAI virus (i.e., fowl plague virus). Forty-two documented epidemics or limited outbreaks of HPAI have occurred since the discovery of AI viruses as the cause of fowl plague in 1955. Since 1959 with wellmaintained virus archives, most HPAI virus have arisen from changes in LPAI viruses with limited spread of outbreaks and eradication from poultry. However, the Gs/GD H5Nx, Mexican H7N3, and Chinese H7N9 HPAI viruses are concerning because these strains have not been eradicated and still cause poultry outbreaks. In particular, the Gs/GD H5Nx and Chinese $\mathrm{H} 7 \mathrm{~N} 9$ viruses pose a significant pandemic threat to human health. The Gs/GD lineage of H5 has a broad One Health impact as it con- tinues to cause infections, disease, and death in poultry, wild birds, and humans. Furthermore, the Gs/GD lineage outbreak has affected more poultry and countries than the other $41 \mathrm{HPAI}$ outbreaks combined.

Although chicken HPAI viruses are derived from LPAI viruses of aquatic wild birds, the emergence of HPAI virus does not always happen. The mechanisms by which H5/H7 HPAI virus has emerged is via mutation, insertion, or recombination within the HA-more specifically changes in the proteolytic cleavage site. The number of basic amino acids in the HA cleavage site plays a critical role in virulence determining which proteases can cleave HA and in which tissues the AI viruses can replicate. In general, the mechanisms for amino acid insertions in the cleavage site appear to be different in many cases, and for this reason the genetic basis to predict which LPAI viruses will result in the emergence of a HPAI virus remains unclear. The presence or absence of the $\mathrm{N}$-linked glycans and key histidine residues in the HA are reported to influence the AI virus phenotype. In addition, changes in other AIV gene segments can increase or decrease the max- 
D.-H. Lee et al.

imal phenotypic expression of the HA usually through increasing replication efficiency and release. In general, molecular techniques such as next-generation sequencing and reverse genetics have helped to identify changes associated with high virulence. However, significant emphasis on basic research is needed to understand why changes occur only in certain LPAI precursors that increase their pathogenicity, which, once understood, could enhance our ability to predict and subsequently prevent conversion events and potentially lead to a reduced number of HPAI outbreaks. With the ultimate goal of eradication, enhanced active surveillance, education, biosecurity, rapid molecular, and characterization efforts will provide the best opportunity for early detection and elimination of HPAI in domestic poultry.

\section{ACKNOWLEDGMENTS}

The authors acknowledge Jung-Hoon Kwon for technical assistance.

This article has been made freely available online courtesy of TAUNS Laboratories.

\section{REFERENCES}

${ }^{*}$ Reference is also in this collection.

Abdelwhab EM, Veits J, Tauscher K, Ziller M, Grund C, Hassan MK, Shaheen M, Harder TC, Teifke J, Stech J, et al. 2016. Progressive glycosylation of the haemagglutinin of avian influenza $\mathrm{H} 5 \mathrm{~N} 1$ modulates virus replication, virulence and chicken-to-chicken transmission without significant impact on antigenic drift. J Gen Virol 97: 3193-3204. doi:10.1099/jgv.0.000648

Abolnik C. 2007. Molecular characterization of H5N2 avian influenza viruses isolated from South African ostriches in 2006. Avian Dis 51: 873-879. doi:10.1637/7953-022107REGR.1

Abolnik C. 2017. Evolution of H5 highly pathogenic avian influenza: sequence data indicate stepwise changes in the cleavage site. Arch Virol 162: 2219-2230. doi:10.1007/ s00705-017-3337-x

Abolnik C, Londt BZ, Manvell RJ, Shell W, Banks J, Gerdes GH, Akol G, Brown IH. 2009. Characterisation of a highly pathogenic influenza A virus of subtype H5N2 isolated from ostriches in South Africa in 2004. Influenza Other Respir Viruses 3: 63-68. doi:10.1111/j.1750-2659.2009 .00074.x

Alexander DJ. 2000. The history of avian influenza in poultry. World Poultry Nov: 7-8.
Alexander DJ, Brown IH. 2009. History of highly pathogenic avian influenza. Rev Sci Tech 28: 19-38. doi:10.20506/rst .28.1.1856.

Alexander DJ, Wood GW. 1993. Highly pathogenic avian influenza diagnosis: past experience, and future problems. In Proceedings of the European Commission Meeting on Virus Diseases of Poultry-New and Evolving Pathogens, Brussels, 1992, pp. 3-13. CEC, Brussels.

Alexander DJ, Parsons G, Manvell RJ. 1986. Experimental assessment of the pathogenicity of eight avian influenza $A$ viruses of H5 subtype for chickens, turkeys, ducks and quail. Avian Pathol 15: 647-662. doi:10.1080/ 03079458608436328

Alexander DJ, Lister SA, Johnson MJ, Randall CJ, Thomas PJ. 1993. An outbreak of highly pathogenic avian influenza in turkeys in Great Britain in 1991. Vet Rec 132: 535536. doi:10.1136/vr.132.21.535

Alexander DJ, Capua I, Koch G. 2008. Highly pathogenic avian influenza outbreaks in Europe, Africa and Asia since 1959, excluding the Asian H5N1 virus outbreaks. In Avian influenza (ed. Swayne DE), pp. 217-237. Blackwell Publishing, Ames, Iowa.

Anonymous. 1976. The outbreak of fowl plague in Victoria. In Annual report, pp. 4-6. Division of Animal Health, Department of Agriculture, Victoria.

Banks J, Plowright L. 2003. Additional glycosylation at the receptor binding site of the hemagglutinin (HA) for $\mathrm{H} 5$ and $\mathrm{H} 7$ viruses may be an adaptation to poultry hosts, but does it influence pathogenicity? Avian Dis 47: 942-950. doi:10.1637/0005-2086-47.s3.942

Banks J, Speidel EC, McCauley JW, Alexander DJ. 2000. Phylogenetic analysis of $\mathrm{H} 7$ haemagglutinin subtype influenza A viruses. Arch Virol 145: 1047-1058. doi:10 $.1007 / \mathrm{s} 007050050695$

Banks J, Speidel ES, Moore E, Plowright L, Piccirillo A, Capua I, Cordioli P, Fioretti A, Alexander DJ. 2001. Changes in the haemagglutinin and the neuraminidase genes prior to the emergence of highly pathogenic $\mathrm{H} 7 \mathrm{~N} 1$ avian influenza viruses in Italy. Arch Virol 146: 963-973. doi:10 $.1007 / \mathrm{s} 007050170128$

Barr DA, Kelly AP, Badman RT, Campey AR, O’Rourke MD, Grix DC, Reece RL. 1986. Avian influenza on a multi-age chicken farm. Aust Vet J 63: 195-196. doi:10.1111/j.17510813.1986.tb02976.x

Bashiruddin JB, Gould AR, Westbury HA. 1992. Molecular pathotyping of two avian influenza viruses isolated during the Victoria 1976 outbreak. Aust Vet J 69: 140-142. doi:10 .1111/j.1751-0813.1992.tb07485.x

Becker WB. 1966. The isolation and classification of Tern virus: influenza A-Tern South Africa-1961. J Hyg (Lond) 64: 309-320. doi:10.1017/S0022172400040596

Berhane Y, Hisanaga T, Kehler H, Neufeld J, Manning L, Argue C, Handel K, Hooper-McGrevy K, Jonas M, Robinson J, et al. 2009. Highly pathogenic avian influenza virus a (H7N3) in domestic poultry, Saskatchewan, Canada, 2007. Emerg Infect Dis 15: 1492-1495. doi:10.3201/ eid1509.080231

Bogs J, Veits J, Gohrbandt S, Hundt J, Stech O, Breithaupt A, Teifke JP, Mettenleiter TC, Stech J. 2010. Highly pathogenic H5N1 influenza viruses carry virulence determinants beyond the polybasic hemagglutinin cleavage site. PLoS ONE 5: e11826. doi:10.1371/journal.pone.0011826 
Bosch FX, Orlich M, Klenk HD, Rott R. 1979. The structure of the hemagglutinin, a determinant for the pathogenicity of influenza viruses. Virology 95: 197-207. doi:10.1016/ 0042-6822(79)90414-8

Bosch FX, Garten W, Klenk HD, Rott R. 1981. Proteolytic cleavage of influenza virus hemagglutinins: primary structure of the connecting peptide between HA1 and HA2 determines proteolytic cleavability and pathogenicity of Avian influenza viruses. Virology 113: 725-735. doi:10.1016/0042-6822(81)90201-4

Briand FX, Schmitz A, Ogor K, Le Prioux A, Guillou-Cloarec C, Guillemoto C, Allée C, Le Bras MO, Hirchaud E, Quenault $\mathrm{H}$, et al. 2017. Emerging highly pathogenic $\mathrm{H} 5$ avian influenza viruses in France during winter 2015/16: phylogenetic analyses and markers for zoonotic potential. Euro Surveill 22. doi:10.2807/1560-7917.ES.2017.22.9 .30473

Brown I, Abolnik C, Garcia-Garcia J, McCullough S, Swayne DE, Cattoli G. 2017. High-pathogenicity avian influenza outbreaks since 2008, excluding multi-continental panzootic of H5 Goose/Guangdong-lineage viruses. In Animal influenza (ed. Swayne DE), pp. 248-270. WileyBlackwell, Ames, IA

Capua I, Marangon S, Selli L, Alexander DJ, Swayne DE, Pozza MD, Parenti E, Cancellotti FM. 1999. Outbreaks of highly pathogenic avian influenza (H5N2) in Italy during October 1997 to January 1998. Avian Pathol 28: 455-460. doi:10.1080/03079459994470

Capua I, Marangon S, Cancellotti FM. 2003. The 1999-2000 avian influenza (H7N1) epidemic in Italy. Vet Res Commun 27: 123-127. doi:10.1023/B:VERC.0000014128 .68876 .31

* Chen H. 2019. H7N9 viruses. Cold Spring Harb Perspect Med doi: 10.1101/cshperspect.a038349

Cross GM. 1987. The status of avian influenza in poultry in Australia. In Proceedings of the Second International Symposium on Avian Influenza (ed. Easterday BC), pp. 96-103. U.S. Animal Health Association, Richmond, VA.

Dhingra MS, Artois J, Dellicour S, Lemey P, Dauphin G, Von Dobschuetz S, Van Boeckel TP, Castellan DM, Morzaria S, Gilbert M. 2018. Geographical and historical patterns in the emergences of novel highly pathogenic avian influenza (HPAI) H5 and H7 viruses in poultry. Front Vet Sci 5: 84 . doi:10.3389/fvets.2018.00084

Downie JC, Laver WG. 1973. Isolation of a type A influenza virus from an Australian pelagic bird. Virology 51: 259 269. doi:10.1016/0042-6822(73)90426-1

DuBois RM, Zaraket H, Reddivari M, Heath RJ, White SW, Russell CJ. 2011. Acid stability of the hemagglutinin protein regulates $\mathrm{H} 5 \mathrm{~N} 1$ influenza virus pathogenicity. PLoS Pathog 7: e1002398. doi:10.1371/journal.ppat.1002398

Easterday BC, Trainer DO, Tůmová B, Pereira HG. 1968. Evidence of infection with influenza viruses in migratory waterfowl. Nature 219: 523-524. doi:10.1038/219523a0

Easterday BC, Hinshaw VS, Halvorson DA. 1997. Influenza. In Diseases of poultry (ed. Calnek BW, Barnes HJ, Beard CW, et al.), pp. 583-605. Iowa State University Press, Ames, IA.

Eckroade RJ, Silverman-Bachin LA. 1986. Avian influenza in Pennsylvania. The beginning. In Proceedings of the Second International Symposium on Avian Influenza (ed.
Easterday BC), pp. 22-32. U.S. Animal Health Association, Richmond, VA.

Elbers ARW, Fabri THF, de Vries TS, de Wit JJ, Pijpers A, Koch G. 2004. The highly pathogenic avian influenza A (H7N7) virus epidemic in The Netherlands in 2003lessons learned from the first five outbreaks. Avian Dis 48: 691-705. doi:10.1637/7149

FAO. 2006. Summary of confirmed HPAI outbreaks in affected countries. FAO AIDE News-AI Bulletin 41: 9-10.

García M, Crawford JM, Latimer JW, Rivera-Cruz MVZE, Perdue ML. 1996. Heterogeneity in the haemagglutinin gene and emergence of the highly pathogenic phenotype among recent $\mathrm{H} 5 \mathrm{~N} 2$ avian influenza viruses from Mexico. J Gen Virol 77: 1493-1504. doi:10.1099/0022-1317-77-71493

Garten W, Klenk HD. 1983. Characterization of the carboxypeptidase involved in the proteolytic cleavage of the influenza haemagglutinin. J Gen Virol 64: 2127-2137. doi:10.1099/0022-1317-64-10-2127

Gohrbandt S, Veits J, Hundt J, Bogs J, Breithaupt A, Teifke JP, Weber S, Mettenleiter TC, Stech J. 2011. Amino acids adjacent to the haemagglutinin cleavage site are relevant for virulence of avian influenza viruses of subtype H5. J Gen Virol 92: 51-59. doi:10.1099/vir.0.023887-0

Gultyaev AP, Richard M, Spronken MI, Olsthoorn RCL, Fouchier RAM. 2019. Conserved structural RNA domains in regions coding for cleavage site motifs in hemagglutinin genes of influenza viruses. Virus Evol 5: vez034. doi:10.1093/ve/vez034

Harder TC, Werner O. 2006. Avian influenza. In Influenza report (ed. Kamps BS, Hoffmann C, Preiser W). http ://www.influenzareport.com/ir/ai.htm

Hirst M, Astell CR, Griffith M, Coughlin SM, Moksa M, Zeng T, Smailus DE, Holt RA, Jones S, Marra MA, et al. 2004. Novel avian influenza H7N3 strain outbreak, British Columbia. Emerg Infect Dis 10: 2192-2195. doi:10 .3201/eid1012.040743

Horimoto T, Kawaoka Y. 1994. Reverse genetics provides direct evidence for a correlation of hemagglutinin cleavability and virulence of an avian influenza A virus. J Virol 68: $3120-3128$.

Horimoto T, Kawaoka Y. 1997. Biologic effects of introducing additional basic amino acid residues into the hemagglutinin cleavage site of a virulent avian influenza virus. Virus Res 50: 35-40. doi:10.1016/S0168-1702(97) 00050-6

Hulse DJ, Webster RG, Russell RJ, Perez DR. 2004. Molecular determinants within the surface proteins involved in the pathogenicity of $\mathrm{H} 5 \mathrm{~N} 1$ influenza viruses in chickens. J Virol 78: 9954-9964. doi:10.1128/JVI.78.18.9954-9964 .2004

Iglesias I, Martínez M, Muñoz MJ, de la Torre A, SánchezVizcaíno JM. 2010. First case of highly pathogenic avian influenza in poultry in Spain. Transbound Emerg Dis 57: 282-285. doi:10.1111/j.1865-1682.2010.01145.x

ISBOAH. 2016. Highly pathogenic avian influenza. Indiana State Board of Animal Health. www.gov/boah/2390.htm.

Kaleta EF, Rulke CPA. 2008. The beginning and spread of fowl plague ( $\mathrm{H} 7$ high pathogenicity avian influenza) across Europe and Asia (1878-1955). In Avian influenza (ed. Swayne DE), pp. 145-189. Blackwell Publishers, Ames, IA. 
D.-H. Lee et al.

Kawaoka Y, Webster RG. 1985. Evolution of the A/Chicken/ Pennsylvania/83 (H5N2) influenza virus. Virology 146: 130-137. doi:10.1016/0042-6822(85)90059-5

Kawaoka Y, Webster RG. 1988. Sequence requirements for cleavage activation of influenza virus hemagglutinin expressed in mammalian cells. Proc Natl Acad Sci 85: 324-328. doi:10.1073/pnas.85.2.324

Kawaoka Y, Webster RG. 1989. Interplay between carbohydrate in the stalk and the length of the connecting peptide determines the cleavability of influenza virus hemagglutinin. J Virol 63: 3296-3300.

Kawaoka Y, Naeve CW, Webster RG. 1984. Is virulence of $\mathrm{H} 5 \mathrm{~N} 2$ influenza viruses in chickens associated with loss of carbohydrate from the hemagglutinin? Virology 139: 303-316. doi:10.1016/0042-6822(84)90376-3

Kawaoka Y, Nestorowicz A, Alexander DJ, Webster RG. 1987. Molecular analyses of the hemagglutinin genes of H5 influenza viruses: origin of a virulent turkey strain. Virology 158: 218-227. doi:10.1016/0042-6822 (87) $90256-X$

Keiner B, Maenz B, Wagner R, Cattoli G, Capua I, Klenk HD. 2010. Intracellular distribution of NS1 correlates with the infectivity and interferon antagonism of an avian influenza virus (H7N1). J Virol 84: 11858-11865. doi:10.1128/ JVI.01011-10

Lang G, Narayan O, Rouse BT, Ferguson AE, Connell MC. 1968. A new influenza A virus infection in turkeys II. A highly pathogenic variant, A/turkey/Ontario/7732/66. Can Vet J 9: 151-160.

Lee CW, Swayne DE, Linares JA, Senne DA, Suarez DL. 2005. H5N2 avian influenza outbreak in Texas in 2004: the first highly pathogenic strain in the United States in 20 years? J Virol 79: 3692-3702. doi:10.1128/JVI.79.17 $.11412-11421.2005$

Lee CC, Zhu H, Huang PY, Peng L, Chang YC, Yip CH, Li YT, Cheung CL, Compans R, Yang C, et al. 2014. Emergence and evolution of avian H5N2 influenza viruses in chickens in Taiwan. J Virol 88: 5677-5686. doi:10.1128/ JVI.00139-14

Lee DH, Torchetti MK, Killian ML, Berhane Y, Swayne DE. 2017a. Highly pathogenic avian influenza A(H7N9) virus, Tennessee, USA, March 2017. Emerg Infect Dis 23: 1860 1863. doi:10.3201/eid2311.171013

Lee DH, Torchetti MK, Killian ML, Swayne DE. 2017b. Deep sequencing of $\mathrm{H7N} 8$ avian influenza viruses from surveillance zone supports H7N8 high pathogenicity avian influenza was limited to a single outbreak farm in Indiana during 2016. Virology 507: 216-219. doi:10.1016/j.virol .2017 .04 .025

Li W, Godzik A. 2006. Cd-hit: a fast program for clustering and comparing large sets of protein or nucleotide sequences. Bioinformatics 22: 1658-1659. doi:10.1093/bio informatics/btl158

Lu JH, Long JX, Jia LJ, Liu YL, Shao WX, Zhang YM, Liu XF. 2006. Reassortment and modification of hemagglutinin cleavage motif of avian/WSN influenza viruses generated by reverse genetics that correlate with attenuation. Acta Virol 50: 243-249.

Luczo JM, Tachedjian M, Harper JA, Payne JS, Butler JM, Sapats SI, Lowther SL, Michalski WP, Stambas J, Bingham J. 2018. Evolution of high pathogenicity of $\mathrm{H} 5$ avian influenza virus: haemagglutinin cleavage site selection of reverse-genetics mutants during passage in chickens. $S c i$ Rep 8: 11518. doi:10.1038/s41598-018-29944-z

Mair CM, Meyer T, Schneider K, Huang Q, Veit M, Herrmann A. 2014. A histidine residue of the influenza virus hemagglutinin controls the $\mathrm{pH}$ dependence of the conformational change mediating membrane fusion. J Virol 88: 13189-13200. doi:10.1128/JVI.01704-14

Maurer-Stroh S, Lee RT, Gunalan V, Eisenhaber F. 2013. The highly pathogenic H7N3 avian influenza strain from July 2012 in Mexico acquired an extended cleavage site through recombination with host $28 \mathrm{~S}$ rRNA. Virol J 10: e139. doi:10.1186/1743-422X-10-139

Max VK, Herrera JR, Moreira RZ, Rojas HO. 2007. Avian influenza in Chile: a successful experience. Avian Dis 51: 363-365. doi:10.1637/7631-042806R1.1

McNulty MS, Allan GM, McCracken RM, McParland PJ. 1985. Isolation of a highly pathogenic influenza virus from turkeys. Avian Pathol 14: 173-176. doi:10.1080/ 03079458508436216

Mehle A. 2014. Unusual influenza A viruses in bats. Viruses 6: 3438-3449. doi:10.3390/v6093438

Minin VN, Bloomquist EW, Suchard MA. 2008. Smooth skyride through a rough skyline: Bayesian coalescentbased inference of population dynamics. Mol Biol Evol 25: 1459-1471. doi:10.1093/molbev/msn090

Munier S, Larcher T, Cormier-Aline F, Soubieux D, Su B, Guigand L, Labrosse B, Cherel Y, Quere P, Marc D, et al. 2010. A genetically engineered waterfowl influenza virus with a deletion in the stalk of the neuraminidase has increased virulence for chickens. J Virol 84: 940-952. doi:10.1128/JVI.01581-09

Naeem K. 1998. The avian influenza H7N3 outbreak in South Central Asia. In Proceedings of the Fourth International Symposium on Avian Influenza (ed. Swayne DE, Slemons RD), pp. 31-35. USAHA, Richmond, VA.

Naeem K, Hussain M. 1995. An outbreak of avian influenza in poultry in Pakistan. Vet Rec 137: 439-439. doi:10.1136/ vr.137.17.439

Nao N, Yamagishi J, Miyamoto H, Igarashi M, Manzoor R, Ohnuma A, Tsuda Y, Furuyama W, Shigeno A, Kajihara $\mathrm{M}$, et al. 2017. Genetic predisposition to acquire a polybasic cleavage site for highly pathogenic avian influenza virus hemagglutinin. MBio 8. doi:10.1128/mBio .02298-16

OFFLU. 2019. Influenza A cleavage sites. wwwofflunet/ fileadmin/home/en/resource-centre/pdf/Influenza_A_ Cleavage_Sites.pdf.

OIE. 2002. International animal health code. www.oieint/ eng/normes/MCode/A_00003htm.

OIE. 2004. Avian influenza. In International animal health code-2004. OIE, Paris www.oie.int/eng/normes/mcode/ en_chapitre_2.7.12.htm.

OIE. 2016a. Highly pathogenic avian influenza, Italy. Immediate Notification. In OIE disease information. OIE, Paris.

OIE. 2016b. Influenza a cleavage site. www.offlu.net/ fileadmin/home/en/resource-centre/pdf/Influenza_A_ Cleavage_Sites.pdf. OIE.

OIE. 2017a. Highly pathogenic avian influenza, China. Immediate Notification. In OIE disease information. OIE, Paris. 
OIE. 2017b. Highly pathogenic avian influenza, United States of America. Immediate Notification. In OIE disease information. OIE, Paris.

OIE. 2019a. Highly pathogenic avian influenza, Mexico. Immediate Notification. In OIE disease information. OIE, Paris.

OIE. 2019b. Influenza A cleavage site. OFFLU-OIE/FAO. http://www.offlu.net/fileadmin/home/en/resource-centre/ pdf/Influenza_A_Cleavage_Sites.pdf

Pasick J, Handel K, Robinson J, Copps J, Ridd D, Hills K, Kehler H, Cottam-Birt C, Neufeld J, Berhane Y, et al. 2005. Intersegmental recombination between the haemagglutinin and matrix genes was responsible for the emergence of a highly pathogenic H7N3 avian influenza virus in British Columbia. J Gen Virol 86: 727-731. doi:10 .1099/vir.0.80478-0

Perdue ML, García M, Beck J, Brugh M, Swayne DE. 1996. An Arg-Lys insertion at the hemagglutinin cleavage site of an H5N2 avian influenza isolate. Virus Genes 12: 77-84. doi:10.1007/BF00370003

Perdue ML, García M, Senne D, Fraire M. 1997. Virulenceassociated sequence duplication at the hemagglutinin cleavage site of avian influenza viruses. Virus Res 49: 173-186. doi:10.1016/S0168-1702(97)01468-8

Perdue ML, Suarez DL, Swayne DE. 1999. Avian Influenza in the 1990s. Poultry Avian Biol Rev 11: 1-20.

Pereira HG, Tumova B, Law VG. 1965. Avian influenza A viruses. Bull World Health Org 32: 855-860.

Qi W, Jia W, Liu D, Li J, Bi Y, Xie S, Li B, Hu T, Du Y, Xing L, et al. 2018. Emergence and adaptation of a novel highly pathogenic H7N9 influenza virus in birds and humans from a 2013 human-infecting low-pathogenic ancestor. J Virol 92. doi:10.1128/JVI.00921-17

Reed ML, Bridges OA, Seiler P, Kim JK, Yen HL, Salomon R, Govorkova EA, Webster RG, Russell CJ. 2010. The pH of activation of the hemagglutinin protein regulates $\mathrm{H} 5 \mathrm{~N} 1$ influenza virus pathogenicity and transmissibility in ducks. J Virol 84: 1527-1535. doi:10.1128/JVI.02069-09

Richard M, Fouchier R, Monne I, Kuiken T. 2017. Mechanisms and risk factors for mutation from low to highly pathogenic avian influenza virus. Eur Food Saf Auth 14: EN-1287.

Röhm C, Horimoto T, Kawaoka Y, Süss J, Webster RG. 1995. Do hemagglutinin genes of highly pathogenic avian influenza viruses constitute unique phylogenetic lineages? Virology 209: 664-670. doi:10.1006/viro.1995.1301

Röhm C, Süss J, Pohle V, Webster RG. 1996. Different hemagglutinin cleavage site variants of H7N7 in an influenza outbreak in chickens in Leipzig, Germany. Virology 218: 253-257. doi:10.1006/viro.1996.0187

Rojas H, Moreira R, Avalos P, Capua I, Marangon S. 2002 Avian influenza in poultry in Chile. Vet Rec 151: 188.

Rowan MK. 1962. Mass mortality among European Common Terns in South Africa in April-May 1961. British Birds 55: 103-114.

Russell CJ. 2014. Acid-induced membrane fusion by the hemagglutinin protein and its role in influenza virus biology. Curr Top Microbiol Immunol 385: 93-116.

Selleck PW, Gleeson LJ, Hooper PT, Westbury HA, Hansson E. 1997. Identification and characterisation of an H7N3 influenza A virus from an outbreak of virulent avian in- fluenza in Victoria. Aust Vet J 75: 289-292. doi:10.1111/j 1751-0813.1997.tb10099.x

Senne DA, Panigrahy B, Kawaoka Y, Pearson JE, Suss J, Lipkind M, Kida H, Webster RG. 1996. Survey of the hemagglutinin (HA) cleavage site sequence of $\mathrm{H} 5$ and $\mathrm{H} 7$ avian influenza viruses: amino acid sequence at the HA cleavage site as a marker of pathogenicity potential. Avian Dis 40: 425-437. doi:10.2307/1592241

Sims LD, Brown IH. 2008a. Multi-continental epidemic of H5N1 high pathogenicity avian influenza (1996-2007). In Avian influenza (ed. Swayne DE), pp. 251-286. Blackwell, Ames, IA.

Sims LD, Turner AJ. 2008b. Avian influenza in Australia. In Avian influenza (ed. Swayne DE), pp. 239-250. Blackwell Publishing, Ames, IA.

Sims LD, Brown IH. 2017. Multi-continental epidemic of H5N1 high pathogenicity avian influenza (1996-2015). In Avian influenza (ed. Swayne DE), pp. 202-247. Wiley, Ames, IA.

Sims LD, Ellis TM, Liu KK, Dyrting K, Wong H, Peiris M, Guan Y, Shortridge KE. 2003a. Avian influenza in Hong Kong 1997-2002. Avian Dis 47: 832-838. doi:10.1637/ 0005-2086-47.s3.832

Sims LD, Guan Y, Ellis TM, Liu KK, Dyrting K, Wong H, Kung NYH, Shortridge KF, Peiris M. 2003b. An update on avian influenza in Hong Kong 2002. Avian Dis 47: 1083 1086. doi:10.1637/0005-2086-47.s3.1083

Sims L, Harder T, Brown I, Gaidet N, Belot G, Dobschuetz Sv, Kamata A, Kivaria F, Palamara E, Bruni M, et al. 2017. Highly pathogenic H5 avian influenza in 2016 and 2017observations and future perspectives. FOCUS ON, No. 11, November 2017. http://www.fao.org/3/a-i8068e.pdf

Slemons RD, Johnson DC, Osborn JS, Hayes F. 1974. Type-A influenza viruses isolated from wild free-flying ducks in California. Avian Dis 18: 119-124. doi:10.2307/1589250

Smith DJ. 2006. Predictability and preparedness in influenza control. Science 312: 392-394. doi:10.1126/science .1122665

Suarez DL. 2016. Common aspects of animal influenza. In Animal influenza (ed. Swayne DE). Wiley-Blackwell, Ames, IA.

Suarez DL, Senne DA, Banks J, Brown IH, Essen SC, Lee CW, Manvell RJ, Mathieu-Benson C, Moreno V, Pedersen JC, et al. 2004. Recombination resulting in virulence shift in avian influenza outbreak, Chile. Emerg Infect Dis 10: 693-699. doi:10.3201/eid1004.030396

Swayne DE. 2008a. The global nature of avian influenza. In Avian influenza (ed. Swayne DE), pp. 123-143. Blackwell Publishers, Ames, IA.

Swayne DE. 2008b. High pathogenicity avian influenza in the Americas. In Avian influenza (ed. Swayne DE), pp. 191-216. Blackwell Publishing, Ames, IA.

Swayne DE. 2017. The global nature of avian influenza. In Animal influenza (ed. Swayne DE), pp. 177-201. WileyBlackwell, Ames, IA.

Swayne DE, Suarez DL. 2000. Highly pathogenic avian influenza. Rev Sci Tech 19: 463-482. doi:10.20506/rst.19.2 .1230

Swayne DE, Hill RE, Clifford J. 2017. Safe application of regionalization for trade in poultry and poultry products during highly pathogenic avian influenza outbreaks in the 
D.-H. Lee et al.

USA. Avian Pathol 46: 125-130. doi:10.1080/03079457 .2016 .1257775

Swayne DE, Suarez DL, Sims L. 2020. Influenza. In Diseases of poultry (ed. Swayne DE, Boulianne M, Logue C, McDougald LD, Nair V, Suarez DL), pp. 210-256. Wiley, Ames, IA.

Turner AJ. 1976. The isolation of fowl plague virus in Victoria. Aust Vet J 52: 384. doi:10.1111/j.1751-0813.1976 .tb09503.x

USAHA. 1985. Report of the Committee on Transmissible Diseases of Poultry and Other Species. In Proceedings of the United States Animal Health Association. Proceedings of the 89th Annual Meeting of the US Animal Health Association, pp. 296-305. Richmond, VA.

USDA. 2017. Final report for the 2017 outbreak of highly pathogenic avian influenza (HPAI)/low pathogenicity avian influenza (LPAI) in the Southeastern United States. https://www.aphis.usda.gov/animal_health/emergency_ management/downloads/hpai/h7-hpai-lpai-finalreport .pdf, pp. 1-46.

Villareal CL, Flores AO. 1998. The Mexican avian influenza (H5N2) outbreak. In Proceedings of the Fourth International Symposium on Avian Influenza (ed. Swayne DE, Slemons RD), pp. 18-22. U.S. Animal Health Association, Richmond, VA.

Walker JA, Kawaoka Y. 1993. Importance of conserved amino acids at the cleavage site of the haemagglutinin of a virulent avian influenza A virus. J Gen Virol 74: 311-314. doi:10.1099/0022-1317-74-2-311

Walker JA, Molloy SS, Thomas G, Sakaguchi T, Yoshida T, Chambers TM, Kawaoka Y. 1994. Sequence specificity of furin, a proprotein-processing endoprotease, for the hemagglutinin of a virulent avian influenza virus. J Virol 68: 1213-1218.

Webster RG, Bean WJ, Gorman OT, Chambers TM, Kawaoka Y. 1992. Evolution and ecology of influenza A viruses. Microbiol Rev 56: 152-179.

Wells RJH. 1963. An outbreak of fowl plague in turkeys. Vet $\operatorname{Rec}$ 75: 783-786.

Westbury HA. 1998. History of highly pathogenic avian influenza in Australia. In Proceedings of the Fourth Interna- tional Symposium on Avian Influenza (ed. Swayne DE, Slemons RD), pp. 23-30. U.S. Animal Health Association, Richmond, VA

WHO/OIE/FAO_H5N1_Evolution_Working_Group. 2008. Toward a unified nomenclature system for highly pathogenic avian influenza virus (H5N1). Emerg Infect Dis 14: el.

WHO/OIE/FAO_H5N1_Evolution_Working_Group. 2014. Revised and updated nomenclature for highly pathogenic avian influenza A (H5N1) viruses. Influenza Other Respir Viruses 8: 384-388. doi:10.1111/irv.12230

Wong F, Daniels P. 2013. Avian influenza-why it's not going away. The Conversation. http://theconversation .com/avian-influenza-why-its-not-going-away-20038

Wood GW, McCauley JW, Bashiruddin JB, Alexander DJ. 1993. Deduced amino acid sequences at the haemagglutinin cleavage site of avian influenza A viruses of $\mathrm{H}_{5}$ and $\mathrm{H}_{7}$ subtypes. Arch Virol 130: 209-217. doi:10.1007/ BF01319010

Yang L, Zhu W, Li X, Chen M, Wu J, Yu P, Qi S, Huang Y, Shi W, Dong J, et al. 2017. Genesis and spread of newly emerged highly pathogenic H7N9 avian viruses in Mainland China. J Virol 91: e01277-17. https://doi.org/10 .1128/JVI.01277-17

Zaraket H, Bridges OA, Duan S, Baranovich T, Yoon SW, Reed ML, Salomon R, Webby RJ, Webster RG, Russell CJ. 2013a. Increased acid stability of the hemagglutinin protein enhances $\mathrm{H} 5 \mathrm{~N} 1$ influenza virus growth in the upper respiratory tract but is insufficient for transmission in ferrets. J Virol 87: 9911-9922. doi:10.1128/JVI .01175-13

Zaraket H, Bridges OA, Russell CJ. 2013b. The $\mathrm{pH}$ of activation of the hemagglutinin protein regulates $\mathrm{H} 5 \mathrm{~N} 1$ influenza virus replication and pathogenesis in mice. J Virol 87: 4826-4834. doi:10.1128/JVI.03110-12

Zhang X, Chen S, Yang D, Wang X, Zhu J, Peng D, Liu X. 2015. Role of stem glycans attached to haemagglutinin in the biological characteristics of $\mathrm{H} 5 \mathrm{~N} 1$ avian influenza virus. J Gen Virol 96: 1248-1257. doi:10.1099/vir.0 .000082 


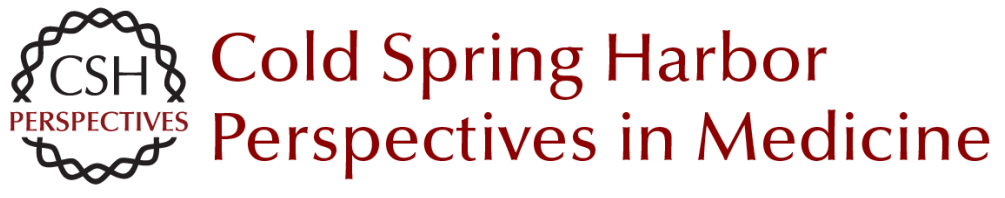

\section{Pathobiological Origins and Evolutionary History of Highly Pathogenic Avian Influenza Viruses}

Dong-Hun Lee, Miria Ferreira Criado and David E. Swayne

Cold Spring Harb Perspect Med 2021; doi: 10.1101/cshperspect.a038679 originally published online January 21, 2020

Subject Collection Influenza: The Cutting Edge

\section{Emerging HxNy Influenza A Viruses \\ William J. Liu, Yan Wu, Yuhai Bi, et al. \\ Equine Influenza \\ Thomas M. Chambers \\ Human Influenza Epidemiology \\ Sukhyun Ryu and Benjamin J. Cowling}

Host Cell Factors That Interact with Influenza

Virus Ribonucleoproteins

Ecco Staller and Wendy S. Barclay

Induction and Evasion of Type-I Interferon

Responses during Influenza A Virus Infection

Raquel Muñoz-Moreno, Carles Martínez-Romero and Adolfo García-Sastre

Structure and Function of Influenza Polymerase Joanna M. Wandzik, Tomas Kouba and Stephen Cusack

H7N9 Influenza Virus in China

Chengjun Li and Hualan Chen

H5 Influenza Viruses in Egypt Rabeh El-Shesheny, Ahmed Kandeil, Ahmed Mostafa, et al.
Antivirals Targeting the Neuraminidase

Larisa Gubareva and Teena Mohan

Accessory Gene Products of Influenza A Virus Rute M. Pinto, Samantha Lycett, Eleanor Gaunt, et al.

Influenza Immunization in the Context of

Preexisting Immunity

Susanne L. Linderman, Ali H. Ellebedy, Carl Davis, et al.

Hemagglutinin Structure and Activities Steven J. Gamblin, Sébastien G. Vachieri, Xiaoli Xiong, et al.

Live Attenuated Cold-Adapted Influenza Vaccines Kanta Subbarao

Next-Generation Influenza Vaccines Masaru Kanekiyo and Barney S. Graham

Selective Genome Packaging Mechanisms of Influenza A Viruses

Takeshi Noda

Systems Biological Analysis of Immune Response to Influenza Vaccination

Mario Cortese, Amy C. Sherman, Nadine G.

Rouphael, et al.

For additional articles in this collection, see http://perspectivesinmedicine.cshlp.org/cgi/collection/ 